\title{
Structure and Origin of the J Anomaly Ridge, Western North Atlantic Ocean
}

\author{
Brian E. TUCHOLKE \\ Woods Hole Oceanographic Institution, Woods Hole, Massachusetts 02543 \\ William J. LudWig' \\ Lamont-Doherty Geological Observatory of Columbia University, Palisades, New York 10964
}

\begin{abstract}
The J Anomaly Ridge is a structural ridge or step in oceanic basement that extends southwest from the eastern end of the Grand Banks. It lies beneath the $J$ magnetic anomaly at the young end (M-4 to M0 ) of the $M$ series magnetic anomalies. Its structural counterpart beneath the $J$ anomaly in the eastern Atlantic is the Madeira-Tore Rise, but this feature has been overprinted by post-middle Cretaceous deformation and volcanism. In order to study the origin and evolution of the $\mathbf{J}$ Anomaly RidgeMadeira-Tore Rise system, we obtained seismic refraction and multichannel reflection profiles across the J Anomaly Ridge near $39^{\circ} \mathrm{N}$ latitude. The western ridge flank consists of a series of crustal blocks downdropped along west-dipping normal faults, but the eastern slope to younger crust is gentle and relatively unfaulted. The western flank also is subparallel to seafloor isochrons, becoming younger to the south. Anomalously smooth basement caps the ridge crest, and it locally exhibits internal, eastward-dipping reflectors similar in configuration to those within subaerially emplaced basalt flows on Iceland. When isostatically corrected for sediment load, the northern part of the J Anomaly Ridge has basement depths about $1400 \mathrm{~m}$ shallower than in our study area, and deep sea drilling has shown that the northern ridge was subaerially exposed during the middle Cretaceous. We suggest that most of the system originated under subaerial conditions at the time of late-stage rifting between the adjacent Grand Banks and Iberia. The excess magma required to form the ridge may have been vented from a mantle plume beneath the Grand Banks-Iberia rift zone and channelled southward beneath the rift axis of the abutting Mid-Atlantic Ridge. Resulting edifice-building volcanism constructed the ridge system between anomalies M-4 and M-0, moving southward along the ridge axis at about $50 \mathrm{~mm} / \mathrm{yr}$. About M0 time, when true drift began between Iberia and the Grand Banks, this southward venting rapidly declined. The results were rapid return of the spreading axis to normal elevations, division of the ridge system into the separate J Anomaly Ridge and Madeira-Tore Rise, and unusually fast subsidence of at least parts of these ridges to depths that presently are near normal. This proposed origin and evolutionary sequence for the J Anomaly Ridge-Madeira-Tore Rise system closely matches events of uplift and unconformity development on the adjacent Grand Banks.
\end{abstract}

\section{INTRODUCTION}

Predrift reconstructions of the North Atlantic show the southwestern edge of the Grand Banks as a sheared (transform) margin that developed during the fragmentation of Laurasia and the initial opening of the North Atlantic Ocean [Pitman and Talwani, 1972; Le Pichon et al., 1977]. The Southeast Newfoundland Ridge has been interpreted as the trace of a fracture zone in oceanic crust marking the continuation of this transform margin. The ridge extends about 900 $\mathrm{km}$ southeast from the southern tip of the Grand Banks with a subsidiary projection, the $J$ Anomaly Ridge (or Spur Ridge), extending to the southwest (Figures 1 and 2).

The J magnetic anomaly [Pitman and Talwani, 1972] is a linear zone of high-amplitude magnetic anomalies, up to about 1000 gammas, associated with crust formed between magnetic anomalies M-0 and M-1 on both sides of the North Atlantic Ocean (Figure 2) [Rabinowitz et al., 1979]. The crust therefore is of Barremian-Aptian age (Early Cretaceous, 108-113 Ma), according to the Larson and Hilde [1975] time scale used throughout this paper. Rabinowitz et al. interpreted the $\mathrm{J}$ anomalies as isochrons formed at the Mid-Atlantic Ridge axis. They modeled the anomalies by assuming that large increases in magnetization intensity exist

\footnotetext{
${ }^{1}$ Now at Gulf Oil Exploration and Production Co., Houston, Texas 77099 .
}

Copyright 1982 by the American Geophysical Union.

Paper number 2B 1215 .

0148-0227/82/002B-1215\$05.00 in crust dating from slightly younger than magnetic anomaly M-1 to slightly younger than M-0, but the amplitude of the anomaly also can be accounted for by an increase in the magnetic layer thickness [Sullivan and Keen, 1978]. In the western North Atlantic the $\mathbf{J}$ anomaly can be traced northeastward from near the eastern end of the New England Seamounts to the eastern edge of the Grand Banks. The anomaly has intermediate amplitudes south of $38^{\circ} \mathrm{N}$ and high amplitudes from there north to the Southeast Newfoundland Ridge [Rabinowitz et al., 1979]. Keen et al. [1977] also suggested that the J anomaly continues northward across the Southeast Newfoundland Ridge into the Newfoundland $\mathrm{Ba}-$ sin, with a $100-\mathrm{km}$ offset; magnetic profiles in this area suggest that the amplitude of the anomaly decreases northward, especially north of the Newfoundland Seamounts. In the eastern Atlantic, the J anomaly follows the Madeira-Tore Rise (MTR) [Luyendyk and Bunce, 1973; Rabinowitz et al., 1979], and it appears to continue northward possibly as far as the western margin of Galicia Bank [Groupe Galice, 1979]. These studies suggest that anomaly amplitudes decrease north and south of the Azores-Gibraltar Ridge in the same fashion and over about the same distances as in the western North Atlantic.

A basement ridge or step generally is coincident with the $J$ anomaly in the western North Atlantic, although it does not strictly parallel isochrons. The ridge is asymmetrical and is defined in seafloor morphology only north of $40^{\circ} \mathrm{N}$, where the name 'Spur Ridge' also has been applied [Gradstein et al., 1977]. To the south between $38^{\circ}$ and $40^{\circ} \mathrm{N}$, the $J$ Anomaly Ridge (JAR) is buried by sediments of the Sohm 


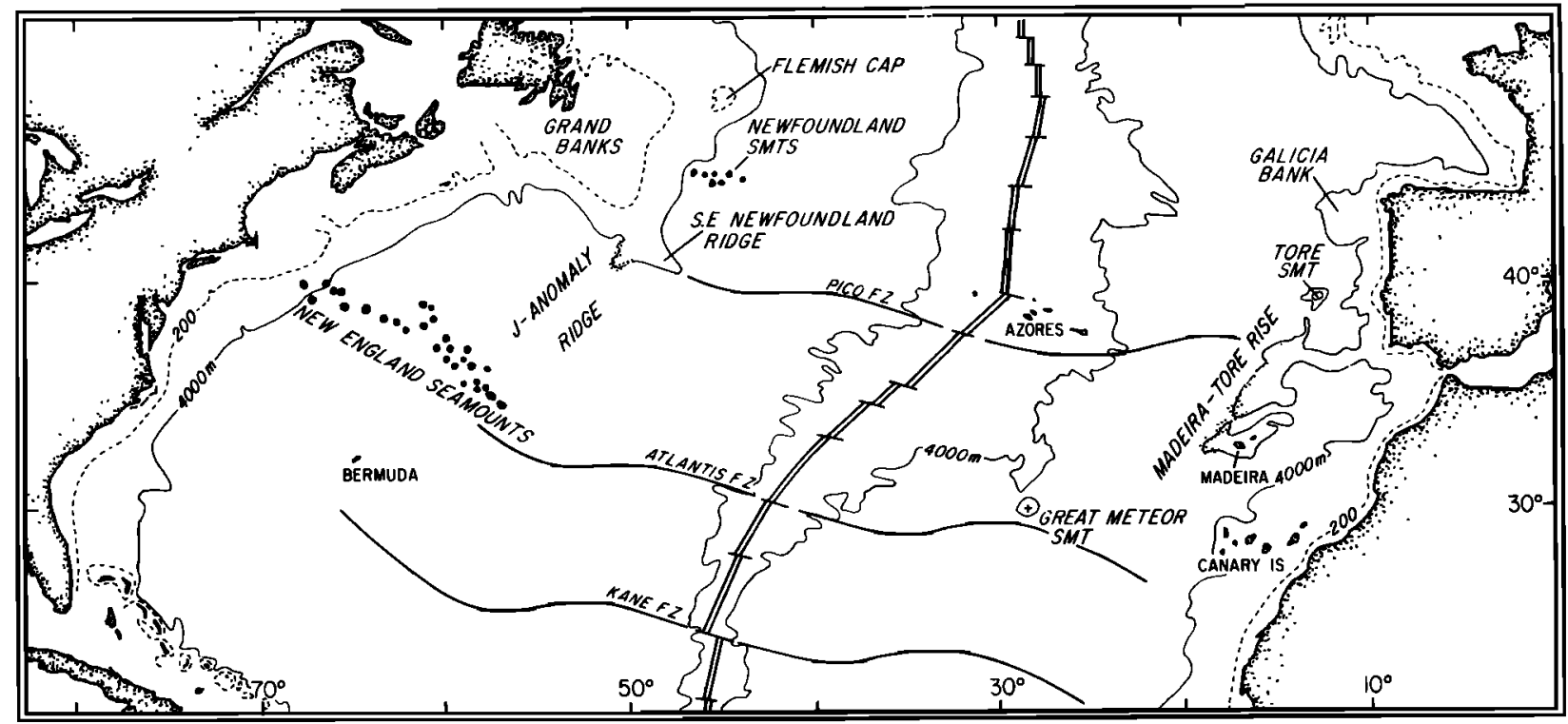

Fig. 1. Location map of the $\mathrm{J}$ Anomaly Ridge and Madeira-Tore Rise in the North Atlantic.

Abyssal Plain, and the ridge crest commonly exhibits a smooth surface (Figures 2 and 3). This part of the ridge slopes gently eastward but sharply westward in a series of $0.5-$ to $1.5-\mathrm{km}$ west-facing scarps. The changes in basement relief alone are not sufficient to account for the amplitude of the $J$ anomaly if a magnetic layer of constant thickness is assumed [Rabinowitz et al., 1979].

A crustal ridge also occurs beneath the Madeira-Tore Rise

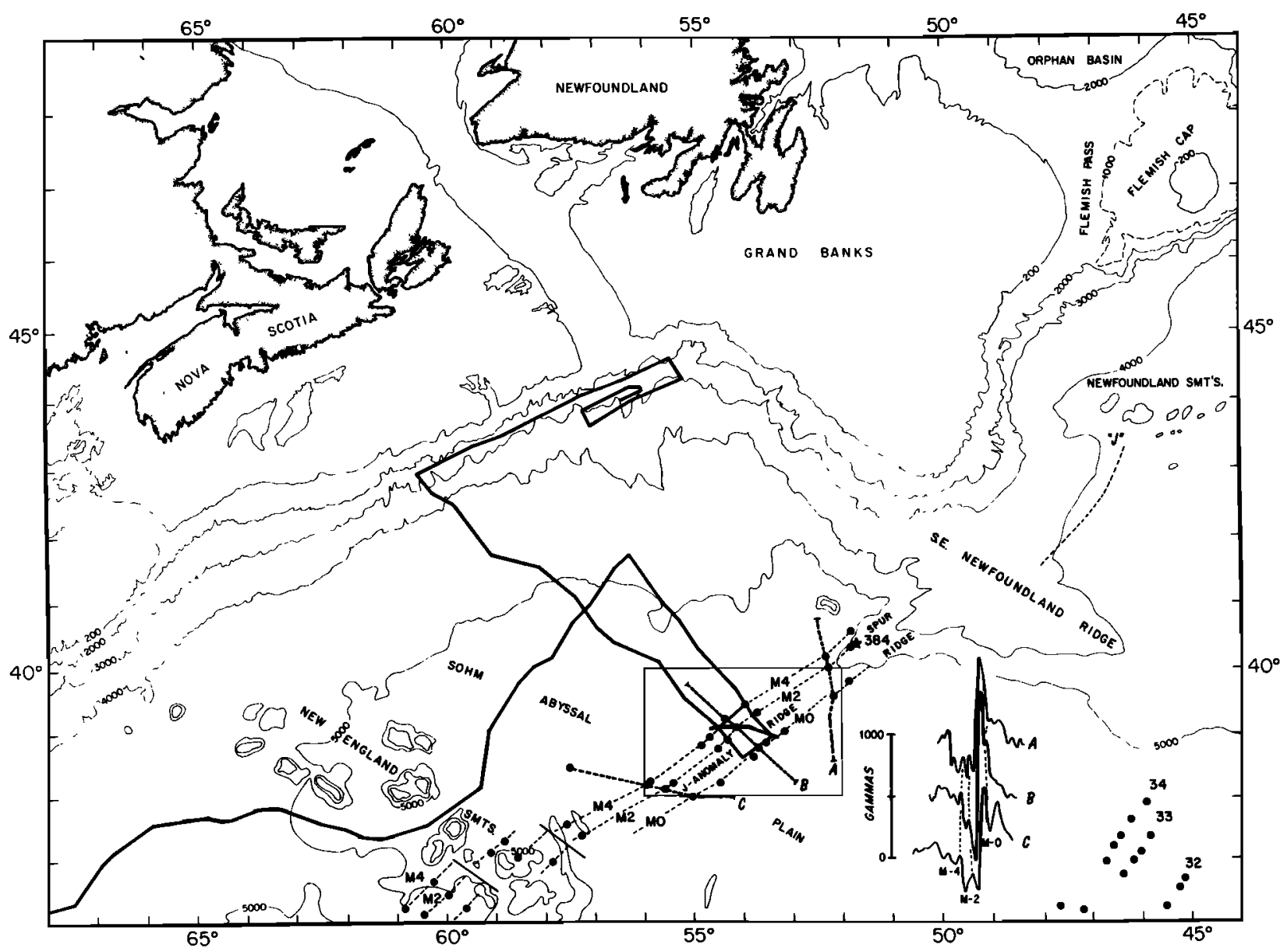

Fig. 2. Location map of Conrad 21-11 MCS tracks (heavy lines). Bathymetry in meters. Black dots are locations of magnetic anomalies, as identified by Rabinowitz et al. [1979]. J anomaly north of Southeast Newfoundland Ridge from Keen et al. [1977]. Inset shows three profiles across the high-amplitude $J$ magnetic anomaly, located by dotted lines across J Anomaly Ridge. Detail of survey work (boxed area) is shown in Figure 4. Star locates DSDP site 384. 

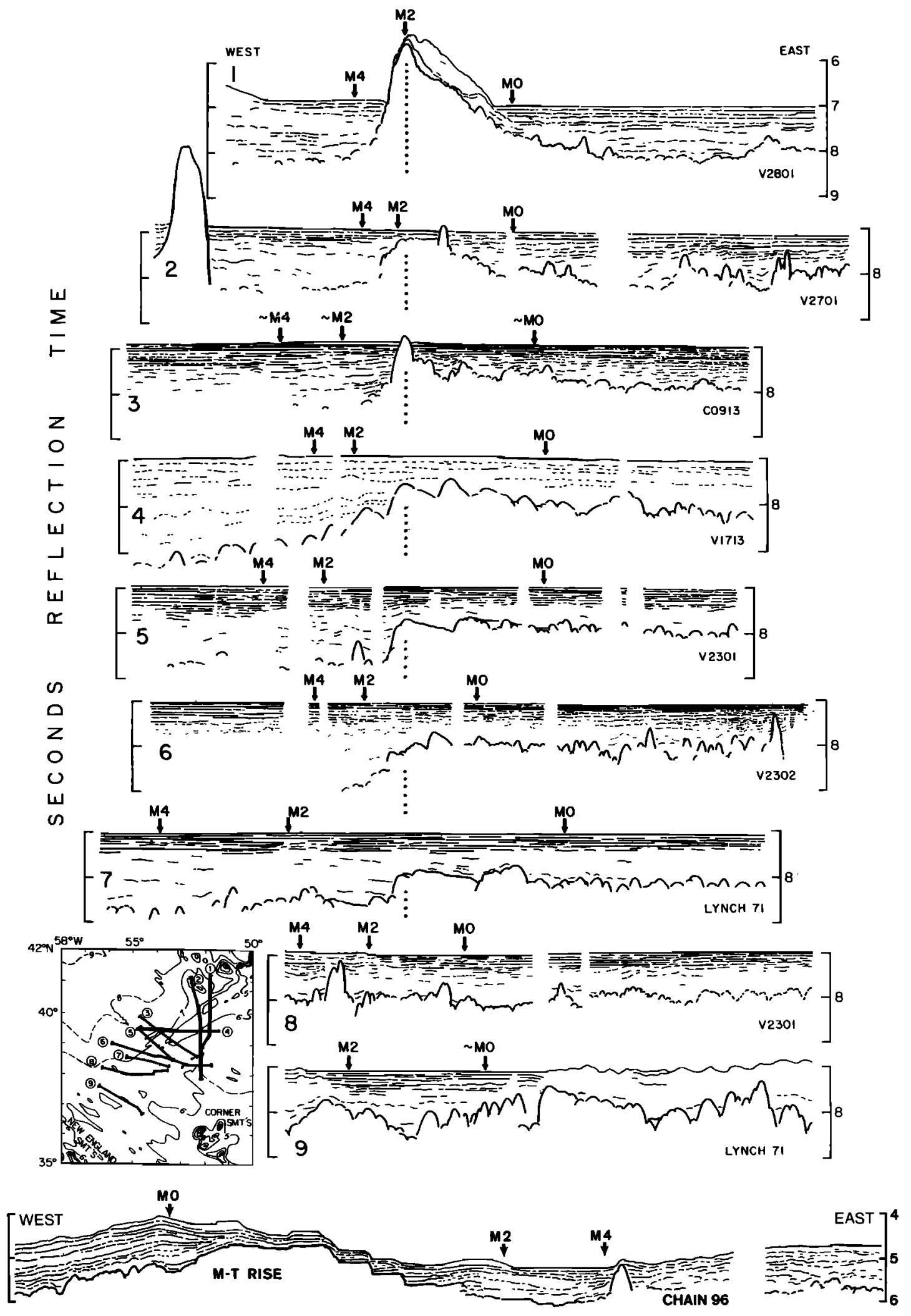

Fig. 3. Tracings of single-channel seismic profiles (1-9) across J Anomaly Ridge, aligned along ridge crest (dotted line), and with M series magnetic anomalies located (modified from Tucholke and Vogt [1979]). Inset shows profile locations on map of depth to basement (in kilometers). Bottom profile shows correlative basement ridge in the eastern North Atlantic; profile is $200 \mathrm{~km}$ long, crossing Madeira-Tore Rise $70 \mathrm{~km}$ north of Madeira. 


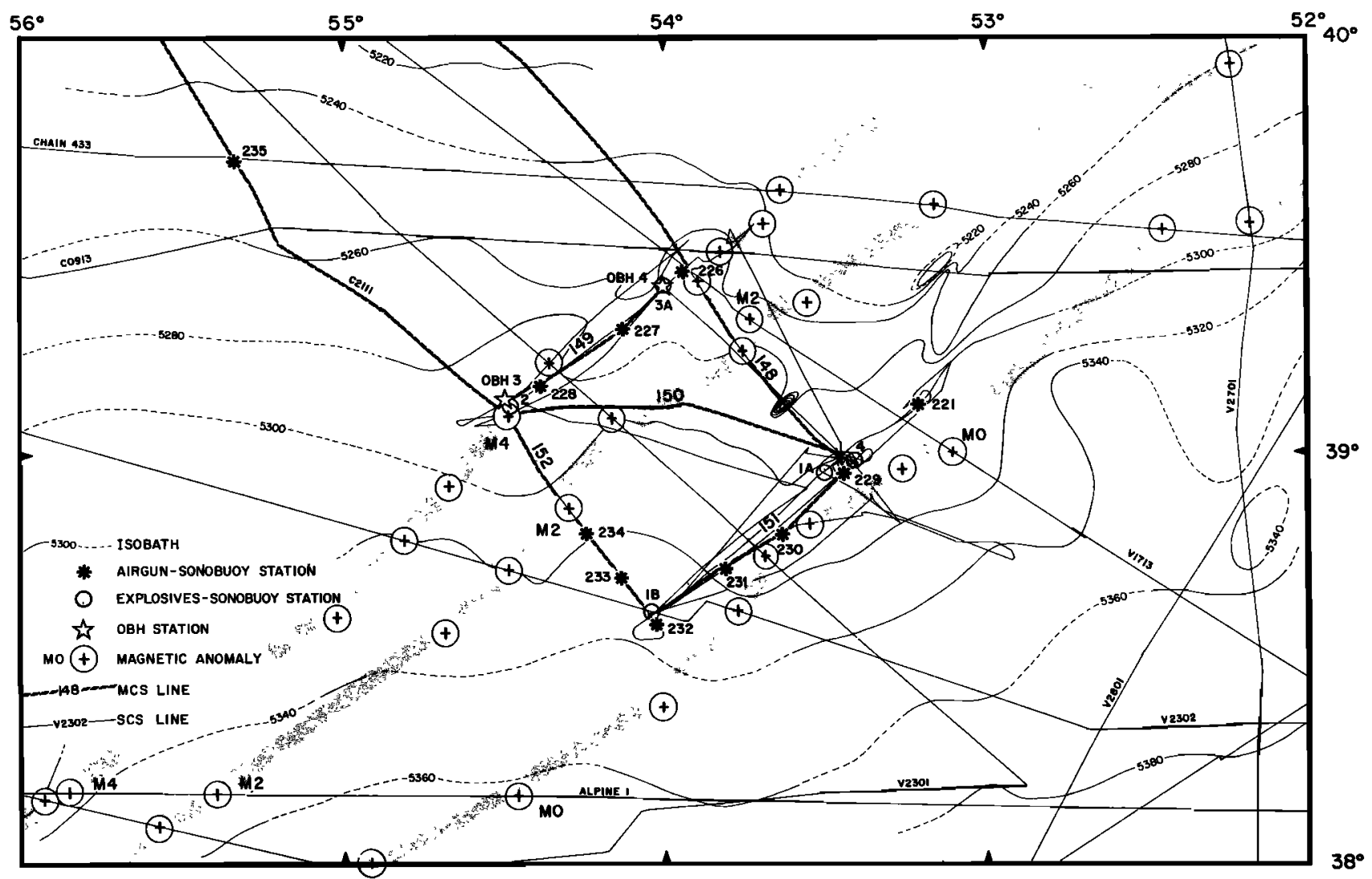

Fig. 4. Location map of Conrad 21-11 track and MCS, OBH, and sonobuoy measurements over the J Anomaly Ridge. Bathymetry in corrected meters.

at the position of the conjugate $\mathrm{J}$ anomaly in the eastern North Atlantic (Figure 1). However, the structure of at least parts of the Madeira-Tore Rise has been modified by late Cretaceous-Tertiary compressional deformation and Neogene volcanism [e.g., Laughton and Whitmarsh, 1974; Watkins, 1973]. Although no detailed study and mapping of seismic reflection data has been made for this region, our examination of a variety of seismic profiles suggests that at least parts of the Madeira-Tore Rise are a mirror image of the $\mathrm{J}$ Anomaly Ridge in terms of general configuration and presence of smooth basement (Figure 3, bottom).

In 1975 , the northern $J$ Anomaly Ridge was drilled on magnetic anomaly $\mathbf{M}-2$ in an attempt to resolve the origin of the ridge and the $\mathrm{J}$ magnetic anomaly (DSDP site 384, Figure 2). Basaltic ocean crust was penetrated at $4234 \mathrm{~m}$ below sea level, and upper Barremian or lower Aptian shallow-water carbonates were cored immediately above basement [Tucholke et al., 1979]. The basalt was not anomalous in either magnetization or composition. However, the later magnetic modeling by Rabinowitz et al. [1979] showed that the J anomaly is best explained by anomalous magnetization (or anomalous magnetic-layer thickness) in crust between anomalies $\mathbf{M}-0$ and $\mathbf{M}-1$, rather than at $\mathbf{M}-2$.

Gradstein et al. [1977] examined geological and geophysical data along the southeastern edge of the Grand Banks and concluded that subsidence of the northern $J$ Anomaly Ridge was very similar to that of the adjacent Grand Banks. Thus they inferred that the cored basalts were flows covering continental crust. Such an explanation seems unlikely in that this part of the ridge extends well to the southwest of the Grand Banks transform margin and has a trend parallel to seafloor isochrons. Furthermore, interpretation of the mag- netic anomalies as part of the Mesozoic $M$ series [Rabinowitz et al., 1978, 1979] and the occurrence of the conjugate Madeira-Tore Rise in the eastern North Atlantic seem to demonstrate conclusively that the J Anomaly Ridge is developed in oceanic crust. Vogt and Einwich [1979] also assumed an oceanic composition, and they suggested that the magnetization changes and (or) thickened magnetic layer associated with the $J$ anomaly originated in response to the transition from a long period of relatively slow seafloor spreading ( $M$ series anomalies) to a period of faster spreading (Cretaceous magnetic quiet zone).

The oceanic basement (seismic layer 2) that forms the J Anomaly Ridge and that lies beneath the Sohm Abyssal Plain farther west seldom is well resolved in single-channel seismic reflection records made with small-volume $\left(20-60 \mathrm{in}^{3}\right)$ airguns. This is due to a thick cover $(0.7-3.5 \mathrm{~km})$ of interbedded hemipelagic and coarse turbiditic sediments that greatly attenuate seismic energy. For this reason, it was not certain that the anomalously smooth 'acoustic basement' of the J Anomaly Ridge observed in single-channel records actually was basaltic crust. In order to better understand the structure and origin of the J Anomaly Ridge, we obtained a series of refraction and multichannel seismic reflection measurements over the ridge near $39^{\circ} \mathrm{N}$ (Figure 4). This area was selected because previous magnetic and single-channel seismic profiles suggested strong development there of both the smooth acoustic basement and the $M$ series anomalies.

\section{METHODS}

Approximately $3300 \mathrm{~km}$ of 24-channel seismic reflection data, 35 sonobuoy reflection/refraction profiles, and three ocean bottom hydrophone (OBH) refraction profiles were 
obtained during a 32-day cruise of the R/V Conrad in July 1978 (Figures 2 and 4). The objectives of the cruise were three-fold. First, we traced key seismic reflecting horizons from south of the New England Seamounts into the Sohm Abyssal Plain and continental rise off Nova Scotia where reflector identification was poorly controlled. Second, we investigated the structure and seismic velocity distribution of the buried J Anomaly Ridge. Finally, we obtained new seismic data bearing on the structure and nature of the 'sedimentary (salt) ridge province' of the central and upper continental rise off Nova Scotia [e.g., Jansa and Wade, 1975; Uchupi and Austin, 1979]. This report describes the results of our seismic work over the J Anomaly Ridge (Figure 4).

\section{Multichannel Seismic Reflection Measurements}

The multichannel seismic (MCS) reflection equipment aboard R/V Conrad consisted of a 2400-m-long, 48-group streamer, four 466 in $^{3}$ airguns, and a DFS IV digital recording system. The airguns were fired at $127 \mathrm{~kg} / \mathrm{cm}^{2}$ (1800 psi) every $18-20 \mathrm{~s}$ at a ship's speed of $9 \mathrm{~km} / \mathrm{hr}$. Shot points were located by satellite navigation and dead reckoning. The data were recorded digitally on magnetic tape at a 4-ms sampling rate and over a recording window of 8-12 s; the data window started just before the seafloor arrival. Common depth point (CDP) processing of the data tapes was done at LamontDoherty Geological Observatory. Standard processing included demultiplexing and CDP gather, semblance velocity analysis, normal moveout correction, stack, and deconvolution as described by Talwani et al. [1977].

\section{Airgun-Sonobuoy Measurements}

Over the 5000-m-deep Sohm Abyssal Plain, the 2.4-km hydrophone array is too short to resolve sediment interval velocities accurately, and SSQ-41A sonobuoys were used to provide velocity/depth information [Houtz et al., 1968; Le Pichon et al., 1968]. These analog recordings were obtained at two frequency bands on a shipboard drum recorder. In addition, refracted waves generated by explosive charges were recorded as oscillograms at several sonobuoy locations and plotted on time-distance diagrams; these data sets were obtained as a by-product of shooting to ocean bottom hydrophones.

\section{Ocean Bottom Hydrophone Measurements}

Ocean bottom hydrophone (OBH) measurements were made by using the Lamont-Doherty prototype instrument [Carmichael et al., 1977]. The OBH is a lightweight, internally recording, pop-up system that separates from a combination ballast-weight/power-supply by a time release mechanism. Anchored about $2 \mathrm{~m}$ above the seafloor, it allows increased resolution of crustal velocity structure and reduced ambiguity in travel time data compared to drifting sonobuoys. For our project, the OBH was modified to permit 12 hours of continuous recording and was fitted with a magnetostrictive pinger for location and navigation purposes [e.g., Francis et al., 1975].

The reduction of seismic refraction data recorded at the seafloor is described by Ewing and Ewing [1961], Davis et al. [1976], and Purdy and Detrick [1978], among other. We recorded refraction profiles in opposite directions at each $\mathrm{OBH}$ location, using explosives as the sound source. After appropriate filtering, the data were plotted as time-distance graphs and interpreted by the conventional slope-intercept method for reversed profiles [e.g., Ludwig et al., 1968].

\section{Basement Morphology ANd Structure}

Multichannel seismic reflection profiles were obtained both perpendicular and parallel to the trend of the $J$ Anomaly Ridge (Figures 5 and 6). Mapped together with previously obtained single-channel profiles, they show clearly that regional structures trend northeast nearly parallel to seafloor isochrons (Figure 7). Aside from a few small, apparently isolated peaks, minimum depths along the ridge crest in the survey area are slightly less than $6.0 \mathrm{~km}$ below sea level. Acoustic basement depths increase northwestward to about $7.5 \mathrm{~km}$ at a position $80 \mathrm{~km}$ from the ridge crest. Toward the southeast, basement dips very gently, reaching depths of only $6.2-6.5 \mathrm{~km}$ before rising into the flank of the MidAtlantic Ridge [Tucholke et al., 1982]. Acoustic basement observed in MCS profiles is unusually smooth over the crest of the ridge, and along line 151 parallel to the ridge crest it is almost perfectly flat for at least $77 \mathrm{~km}$ (Figure 6). The smooth basement is broken by a series of predominantly northwest dipping normal faults that strike northeast parallel to the ridge crest. Many of the fault blocks appear to have rotated, and several faults continue into the overlying sediment column as growth faults (e.g., line 152, Figure 5). The corners of several fault blocks also appear to be truncated to form a nearly horizontal surface (see arrows, Figure 5). The faulted smooth basement extends from crust of about anomaly M-2 age (113 Ma) at least to anomaly M-0 (108 Ma). West of anomaly M-2 the basement becomes an irregular, diffracting horizon that is more typical of oceanic crust, although a few areas of smooth basement persist (lines 148 and 150, Figure 5). A narrow ridge of irregular crust interrupts the smooth basement and bounds a distinct basement step about halfway between anomalies M-2 and M-0 (Figures 5 and 7).

The smooth acoustic basement between the irregular basement ridge and anomaly M-0 is distinctly different from smooth basement farther west because it locally exhibits internal reflectors that dip and diverge toward the east (Figure 5). Intrabasement reflectors elsewhere often appear to be peg-leg multiples generated by a double travel path within the sediment column, but the dipping reflectors cannot be explained in this manner. West of the irregular basement ridge the smooth basement also appears to contain internal reflectors, but it is difficult to distinguish primary events from multiples because the structure has no signifcant dip. Although the basement surface there is much smoother than normal, it nevertheless has some small-scale roughness (indicated by hyperbolic diffractions) that may be partially masked by thin, high-velocity sedimentary beds or basalt flows.

The overall morphologic development of the J Anomaly Ridge system is not strictly parallel to seafloor isochrons. In Figure 8 we plot basement depth, isostatically corrected for loading by overlying sediments, along several seafloor isochrons from approximately magnetic anomaly M-11/M-12 to anomaly M-0. In crust formed through anomaly M-4 time $(117 \mathrm{Ma})$, there is little indication of ridge development; in fact, crustal depths are up to a half kilometer deeper than predicted from the North Atlantic empirical age-depth curve. At anomaly M-2 (113 Ma) the northern part of the ridge becomes well developed adjacent to the Grand Banks; DSDP site 384 recovered upper Barremian or lower Aptian shallow-water carbonates overlying basement on this part of 


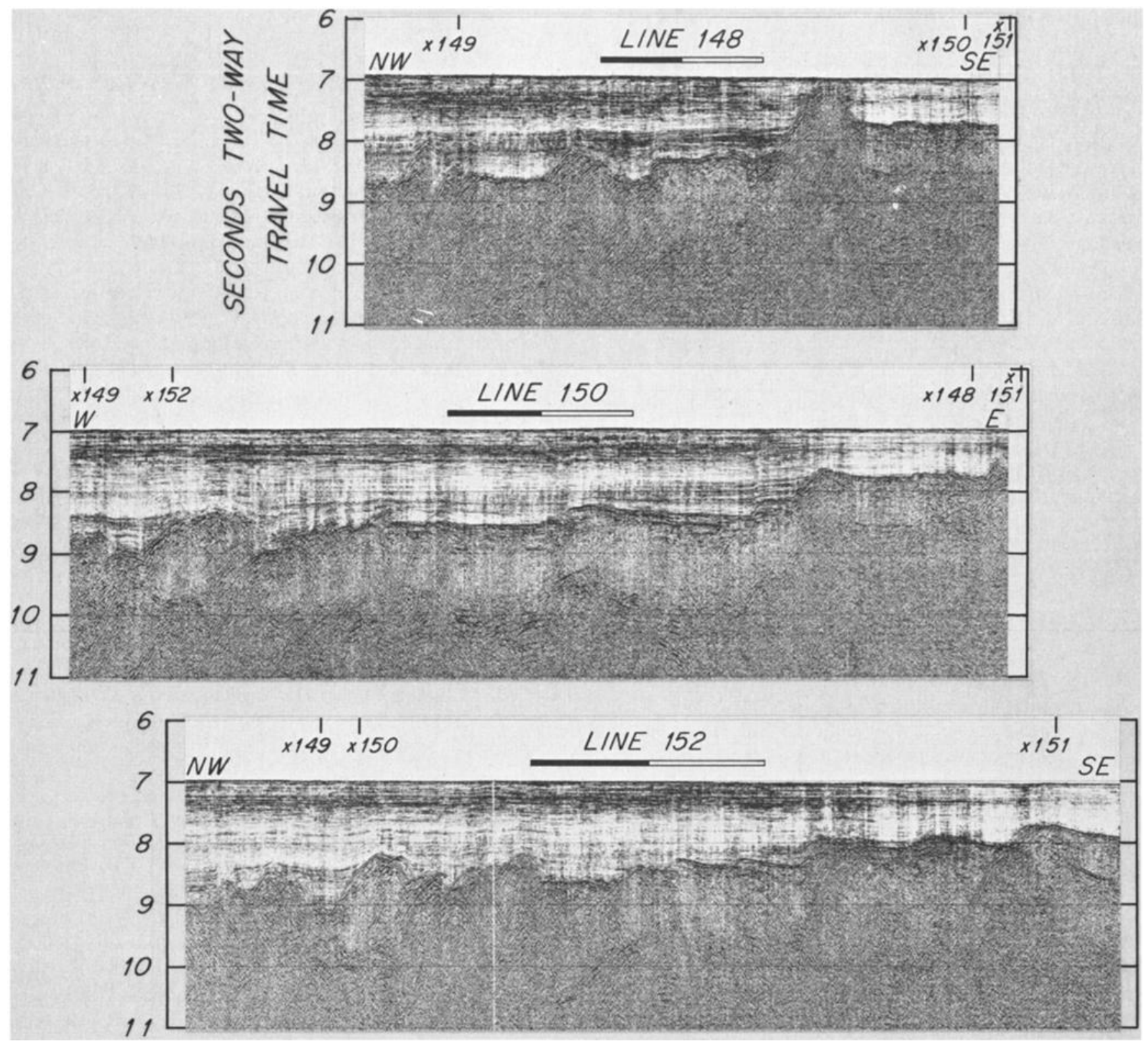

Fig. 5a. MCS stacked record sections for lines 148, 150, and 152 across J Anomaly Ridge. Bandpass filter 10-70 Hz; time-varying gain and Burg deconvolution applied. Scale bars $=20 \mathrm{~km}$. Locations in Figure 4.

the ridge. The magnitude of the positive topographic anomaly decreases along younger crustal isochrons, but there is a clear indication that the topographic anomaly migrated southward along the spreading axis at a rate of about $50 \mathrm{~mm} /$ yr (dotted line, Figure 8). By anomaly M-0 time, the crust is within about $200 \mathrm{~m}$ of normal elevations, and the zone of highest amplitudes of the J magnetic anomaly [Rabinowitz et al., 1979] is restricted to crust north of this morphologic trend (Figure 8, stippled area).

\section{Seismic-Velocity Structure}

The velocities and layer thicknesses determined from unreversed, airgun-sonobuoy profiles are based on the assumption of nondipping layers; thus it is useful to compare them with results from reversed sonobuoy and $O B H$ profiles recorded with explosives to determine true velocity in the presence of dip. Such comparison is possible along the anomaly M-4 isochron and along the crest of the J Anomaly
Ridge near anomaly M-0. Recognizing that both sonobuoy and $\mathrm{OBH}$ refraction profiles are localized measurements which determine average velocities over the line sampled, there is good agreement between the reversed and unreversed measurements (Table 1). The airgun-sonobuoy technique has greater resolution because of the much higher repetition rate of the airgun compared with explosives. In the reversed refraction lines shot with explosives to the OBH (Figures 9 and 10) and to sonobuoys, the shot spacing was not close enough to detect arrivals from acoustic basement; hence the velocities were assumed from nearby airgun-sonobuoy measurements. With one exception (sonobuoy 221), both smooth and rough acoustic basement (as observed in the MCS records) have refraction velocities of $4.5 \mathrm{~km} / \mathrm{s}$ or greater. We therefore interpret acoustic basement as basaltic ocean crust, possibly interbedded with highvelocity clastic sediments in the smooth-basement areas.

The various crustal layers determined by sonobuoy solu- 

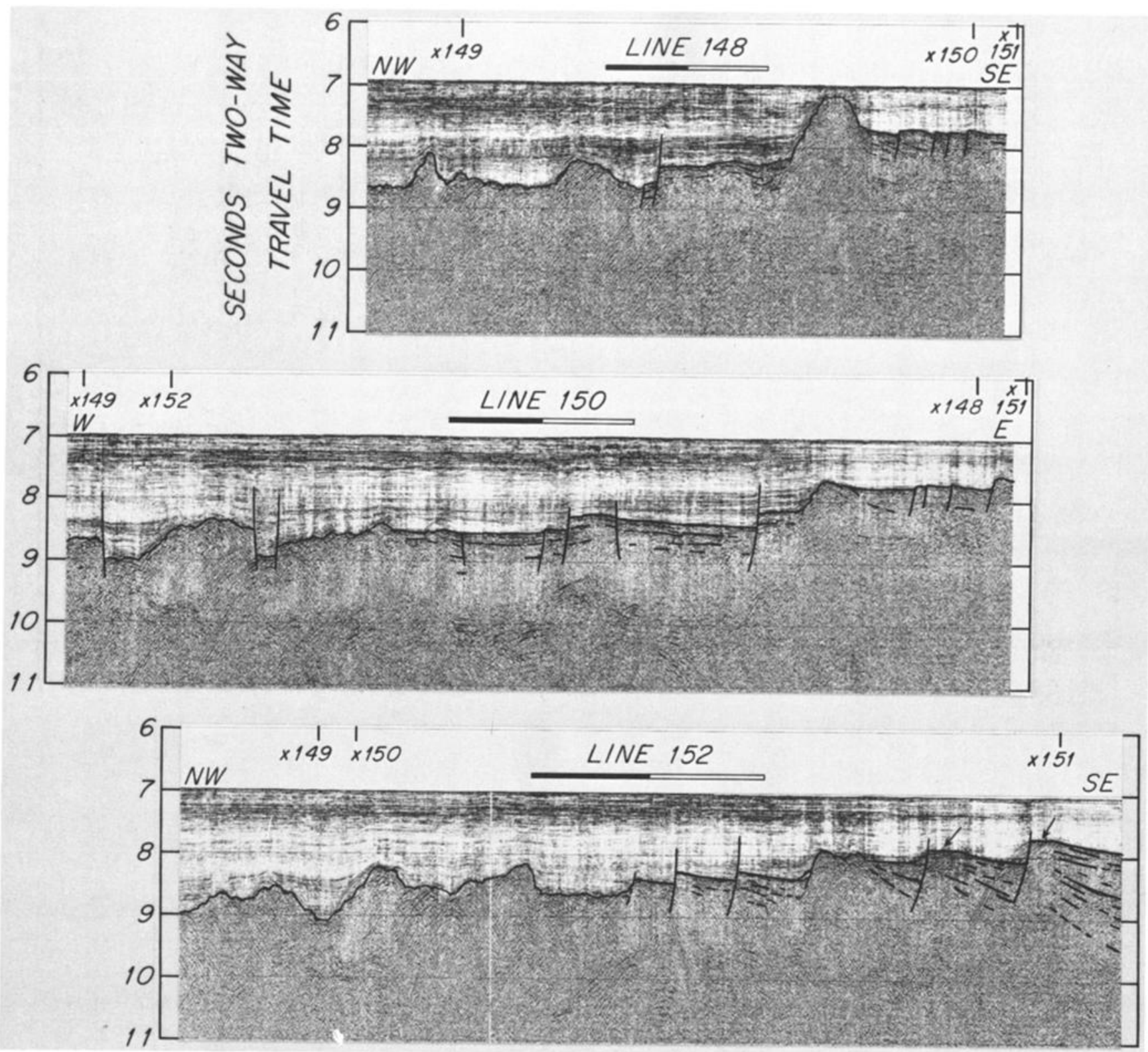

Fig. $5 b . \quad$ Interpretation of record sections in Figure $5 a$.

tions have a fairly wide range of velocities. This is because some sonobuoy solutions do not resolve all layers but give velocities combining several layers, and because the velocities are not corrected for layer dip. For these reasons individual solutions may be misleading in studying geologic structure. In Figure 11 we have partially circumvented this problem by averaging sonobuoy solutions for three crustal age groups: $M-0, M-4$, and a group extending from M-16 (135 Ma) westward into the Jurassic quiet zone $(\sim 155 \mathrm{Ma})$. In comparing the averages in this plot, increases in basement velocity due to increases in sedimentary overburden and hydrostatic pressure are ignored; the changes are small $(\sim 0.2 \mathrm{~km} / \mathrm{s})$ and most likely are compensated by equally small velocity decreases related to increasing temperature [e.g., Chroston et al., 1979] with increasing depth of burial.

The basement velocity structure at anomalies $\mathbf{M - 0}$ and $\mathbf{M -}$ 4 is very nearly the same (Figure 11 ). There is a suggestion that somewhat lower velocities occur 0-2 km subbasement beneath the crest of the $\mathrm{J}$ Anomaly Ridge at anomaly M-0, but because of the small statistical sample it is not known that this difference is significant. More importantly, the velocities within the upper $2.5 \mathrm{~km}$ of older crust ( $>$ M-16) are uniformly $0.4-1.1 \mathrm{~km} / \mathrm{s}$ higher than at $\mathrm{M}-0$. This difference is exemplified in the shallowest crust where measured velocities for the older basement range from 4.95 to $5.75 \mathrm{~km} / \mathrm{s}$, but for M-0 basement all values but one are in the range 4.5-4.7 $\mathrm{km} / \mathrm{s}$ (Table 1 ).

The differences in crustal velocity structure are illustrated in a cross section extending from the $\mathrm{J}$ Anomaly Ridge northwest toward the Nova Scotian margin (Figure 12). As shown by the isovelocity contours, a thick, lower velocity crustal section is associated with the $J$ Anomaly Ridge beginning approximately at the time of anomaly M-4. The same trend exists if the previously developed 'velocity layer' conventions of Houtz and Ewing [1976] and Houtz [1980] are used. These authors designated crustal velocities with extremal ranges of about $4.8-5.6 \mathrm{~km} / \mathrm{s}$ as 'layer $2 \mathrm{~B}$ ' and velocities less than $4.1 \mathrm{~km} / \mathrm{s}$ as 'layer $2 \mathrm{~A}$.' With the exception of 


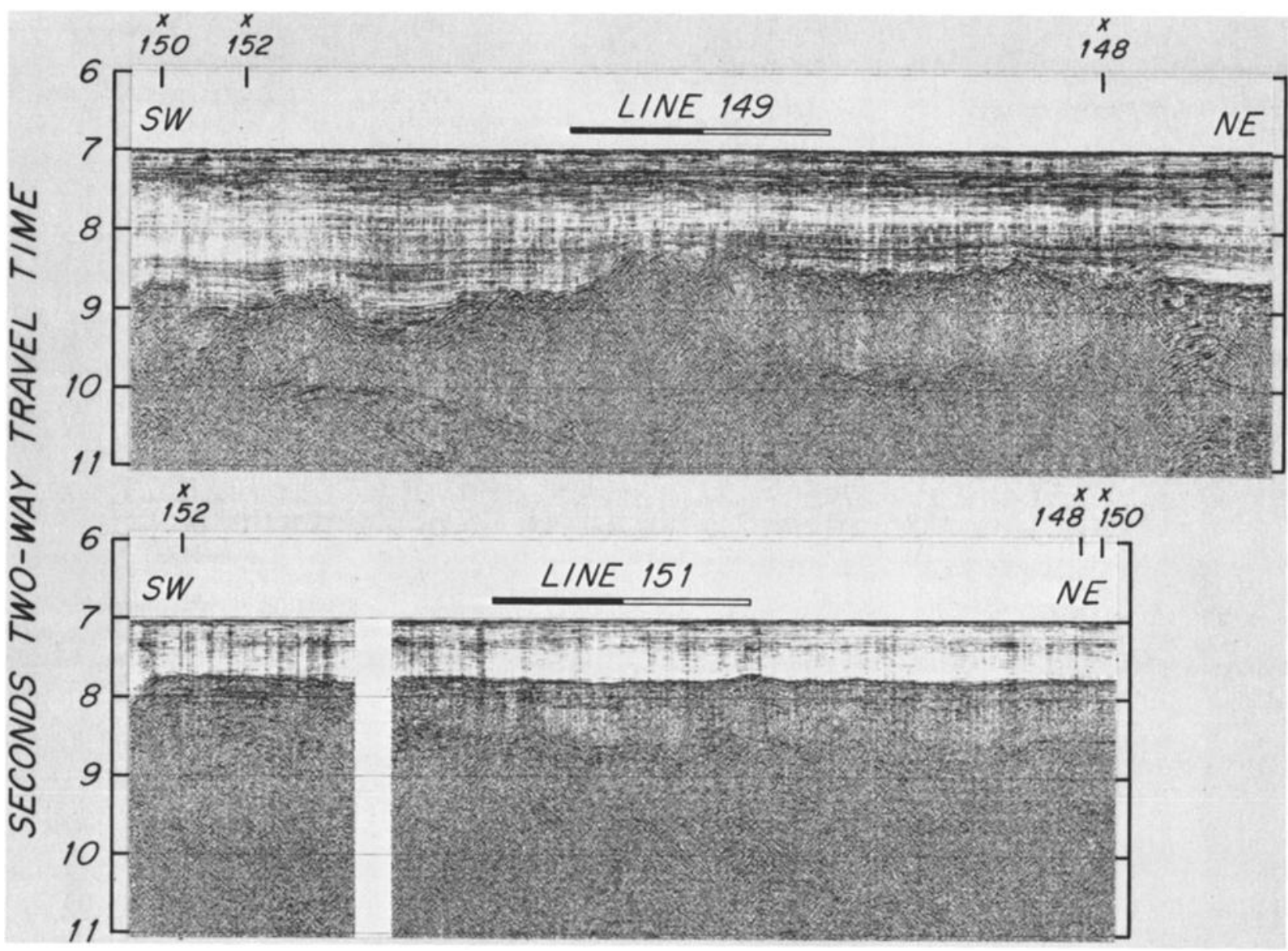

Fig. 6. MCS stacked record sections for line 149 along anomaly M-4 isochron (top) and for line 151 near M-0 isochron at crest of $\mathbf{J}$ Anomaly Ridge (bottom). Bandpass filter 10-70 $\mathrm{Hz}$; time-varying gain and Burg deconvolution applied. Scale bars $=20 \mathrm{~km}$. Locations in Figure 4.

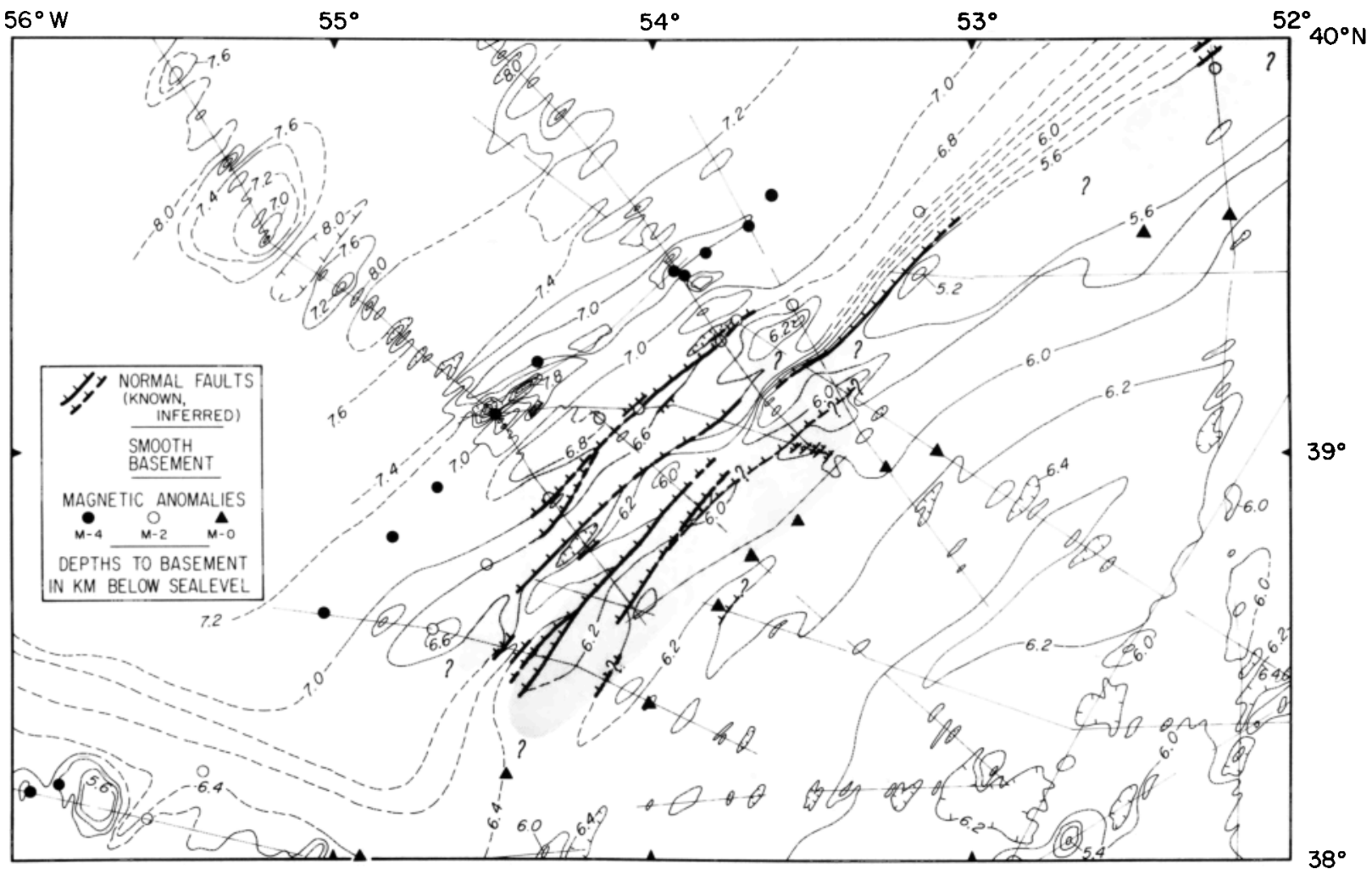

Fig. 7. Map of depth to basement and structure of J Anomaly Ridge. Track control shown by light solid lines. 


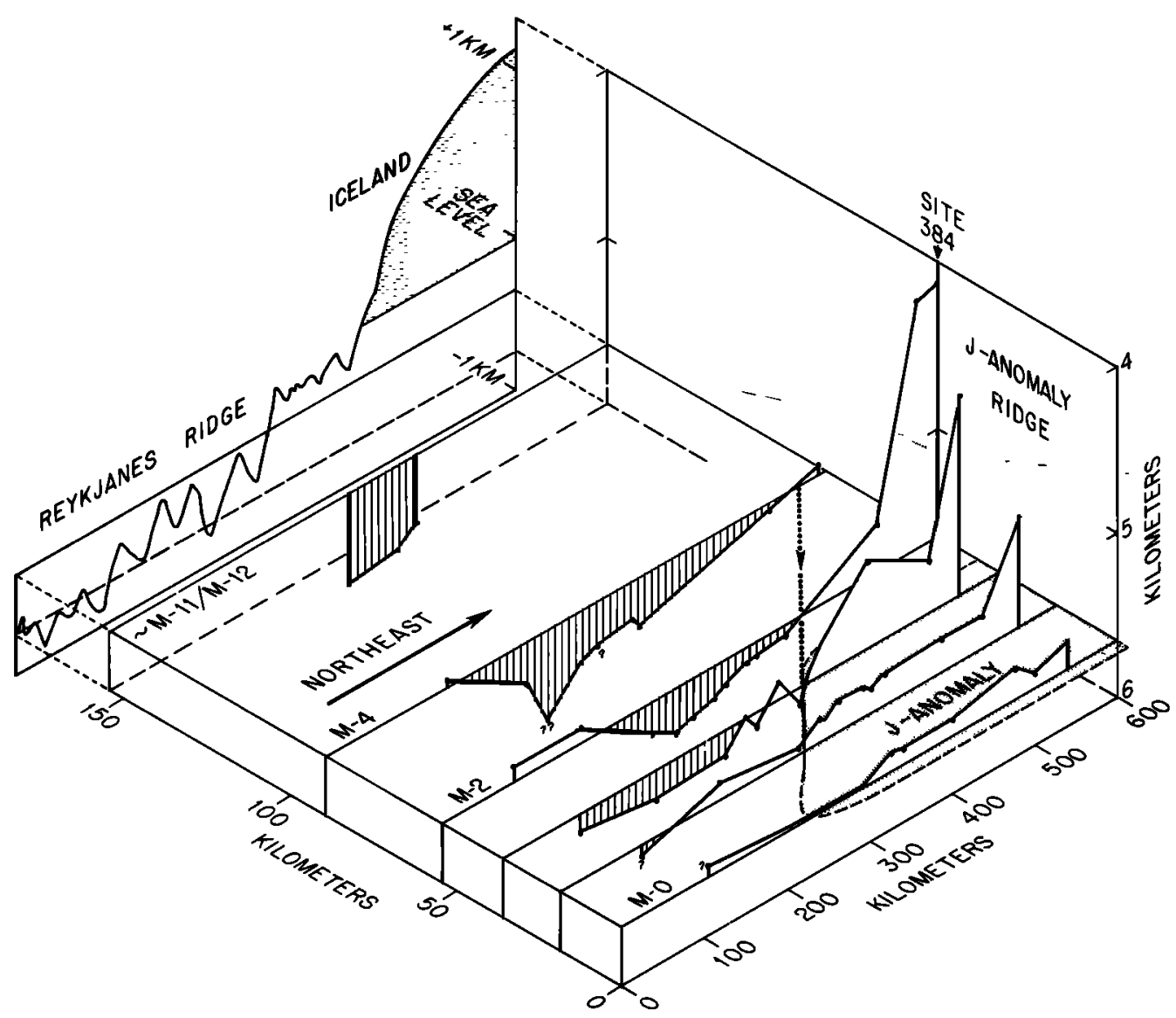

Fig. 8. Perspective diagram of basement depths (corrected for isostatic loading by sediments) along isochrons in area of J Anomaly Ridge southwest of DSDP site 384. Vertical ruling highlights depths below empirical age-depth curve of Tucholke and Vogt [1979]; depths above curve are unpatterned. Stippled area shows zone of anomalous magnetization between anomalies M-1 and M-0 proposed by Rabinowitz et al. [1979] to account for J anomaly. Dotted line shows approximate trend of southward ridge migration between anomalies $\mathbf{M}-4$ to near $\mathbf{M}-0$; it intersects $\mathbf{M}-0$ near $38^{\circ} \mathrm{N}$, where $\mathrm{J}$ anomaly amplitudes decrease markedly to the south. Axial profile of Iceland and Reykjanes Ridge at upper left [from Vogt, 1974] is shown for comparison of vertical and horizontal scales.

sonobuoy 221 , there are no velocities in the layer $2 \mathrm{~A}$ range in our study area. Layer $2 B$ is less than a kilometer thick in older crust beneath the Sohm Abyssal Plain, but it is 1.5-2 km thick beneath the flank and crest of the J Anomaly Ridge (Figure 11). Farther east beneath 45-100 Ma old seafloor, the shallowest crustal layer also appears to have velocities characteristic of layer $2 \mathrm{~B}$, but the layer thickness there is only about $1 \mathrm{~km}$ [Houtz and Ewing, 1976; Houtz, 1980]. Hence the J Anomaly Ridge appears to have an anomalously thick layer 2B. This structure is not reflected in the gravity field, which shows a nearly flat free-air anomaly that indicates isostatic compensation at depth.

\section{Origin of the J Anomaly Ridge}

To determine the origin of the J Anomaly Ridge (and its eastern Atlantic counterpart, the Madeira-Tore Rise), it is useful to consider several geologic analogs in Iceland and the Reykjanes Ridge. The parallels in structure and morphology are quite striking, and they are useful in interpreting both the paleodepth and the mechanism of formation of the J Anomaly Ridge/Madeira-Tore Rise System.

A variety of observations indicates that much of the $J$ Anomaly Ridge was formed at or even above sea level. The dipping reflectors beneath the smooth basement of the $J$
Anomaly Rdge (line 152, Figure 5) are very similar to those observed beneath Iceland [Zverev et al., 1980a, b] in that they dip and diverge toward the accretion axis, and they tend to be rather short $(\sim 10 \mathrm{~km})$ reflective segments rather than laterally extensive horizons. Geologic and kinematic models proposed by Bodvarsson and Walker [1964] and Pálmason [1973, 1980], respectively, explain the Icelandic units as subaerial flows that thicken toward the spreading center; subsidence near the spreading center is due to loading by subsequent flow units. Assuming a relatively fixed distance over which flow units normally spread, the units ultimately offlap in the direction of the continually widening rift zone. Similar dipping intrabasement reflectors have been recognized at the edge of several passive continental margins, and these also are thought to be characteristic of subaerial seafloor spreading associated with initial accretion of ocean crust [e.g., Mutter et al., 1982].

On the J Anomaly Ridge the normal faults that dip away from the spreading axis also are like those observed in Iceland [Zverev et al., 1980a] and in the Icelandic insular slope adjacent to the Reykjanes Ridge [Egloff and Johnson, 1979]. We presume that they result principally from increased thermal contraction with distance from the spreading axis. Saemundsson [1967] observed that some Icelandic normal faults have greater displacement in older strata than 


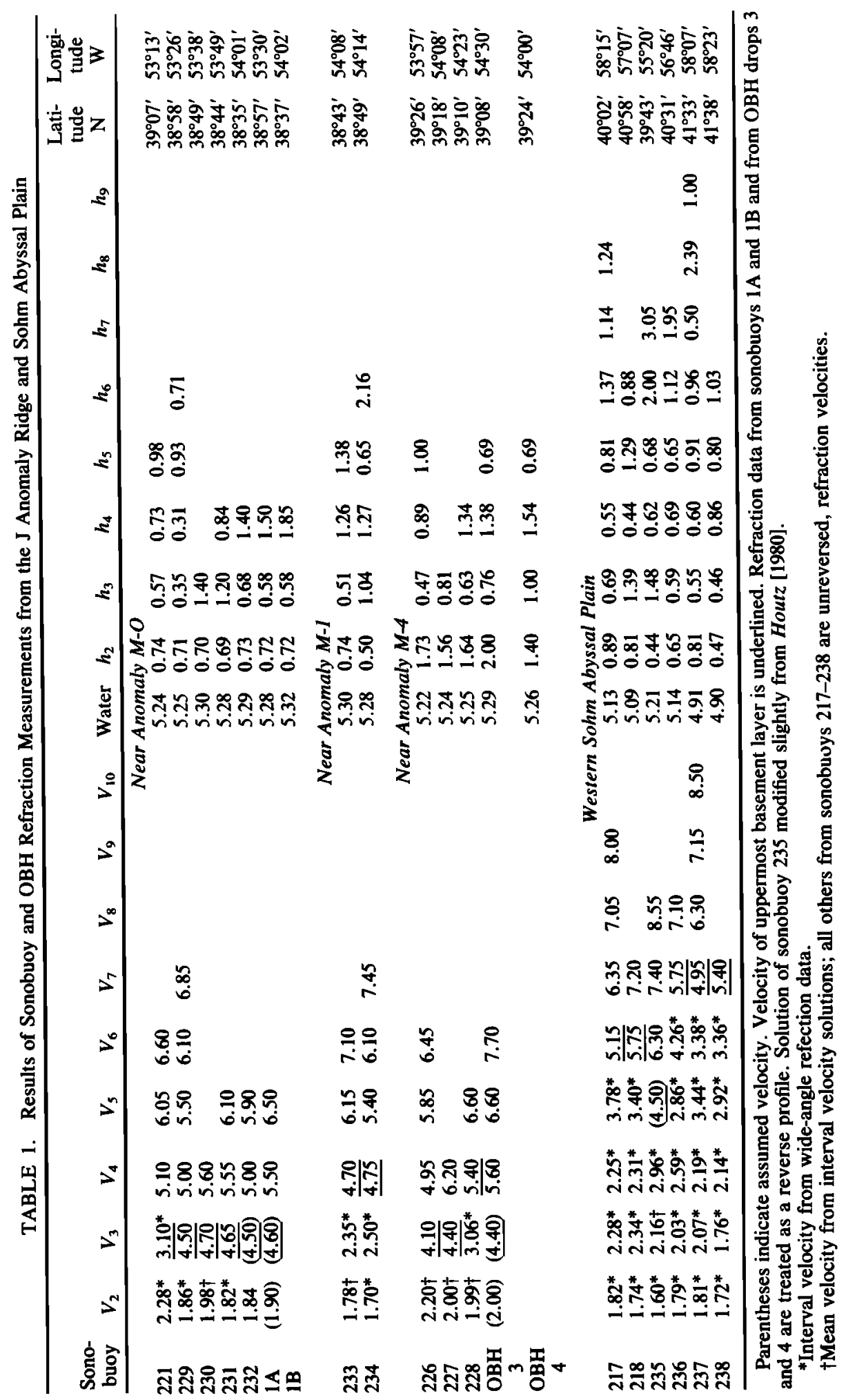




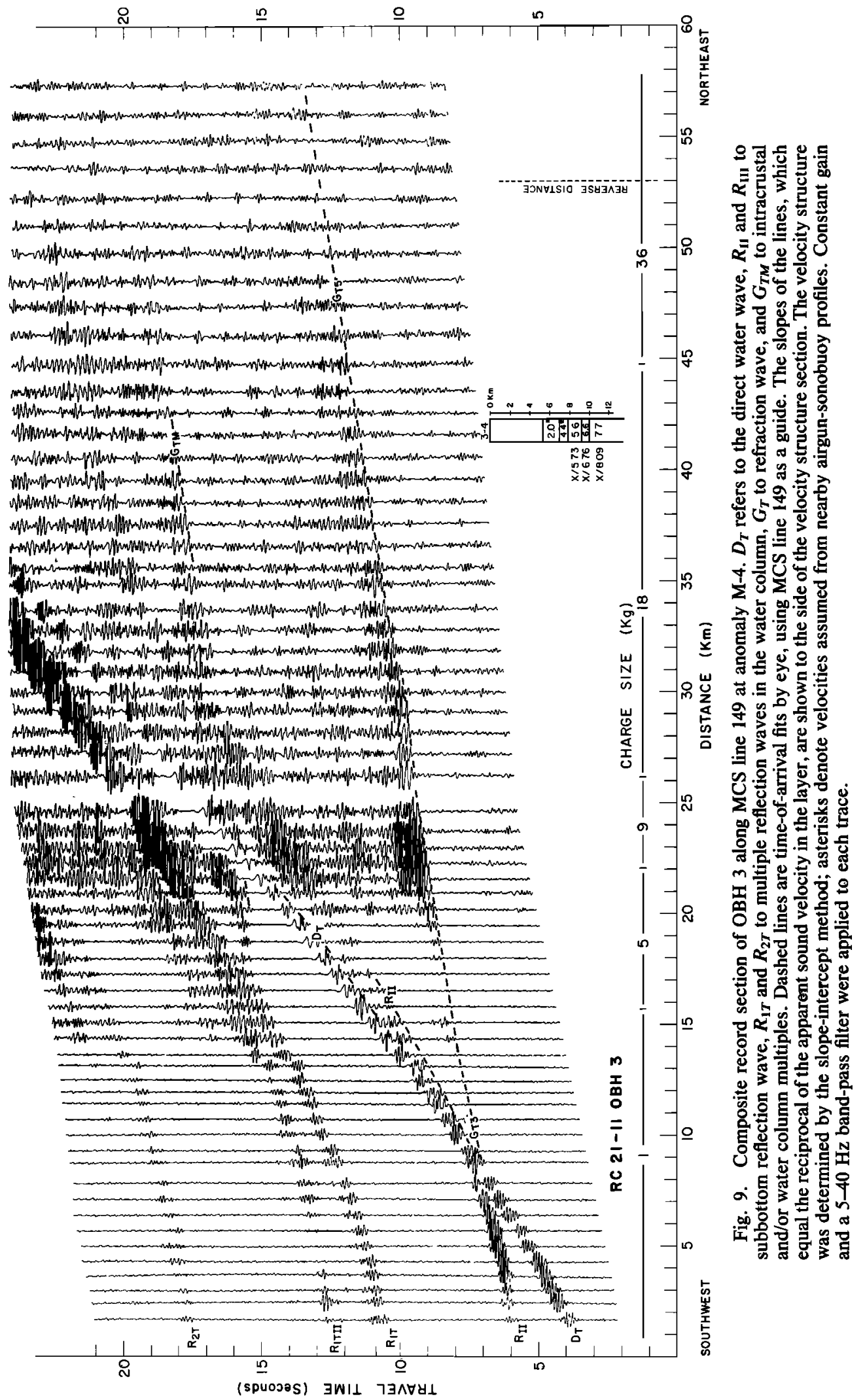




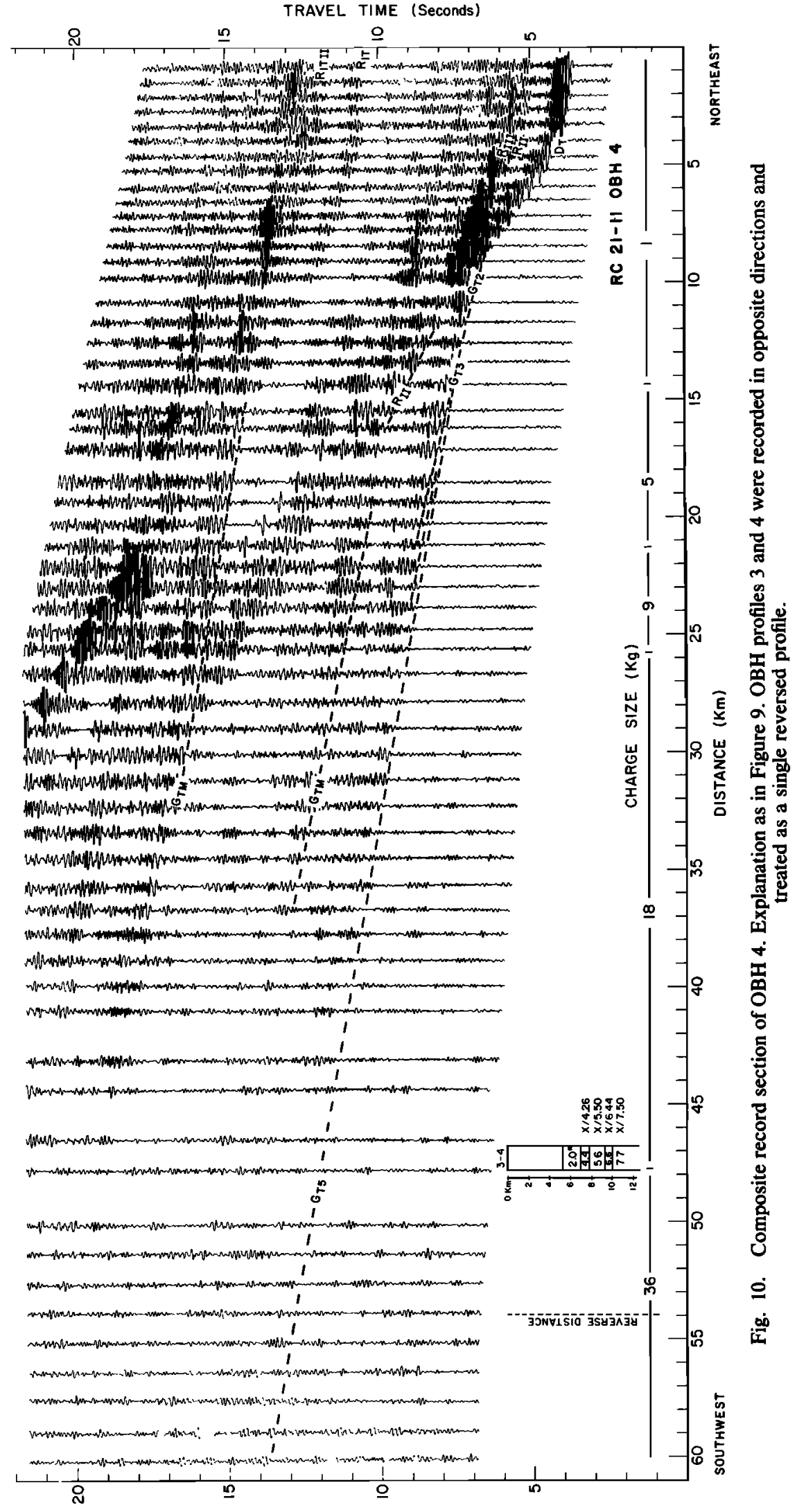




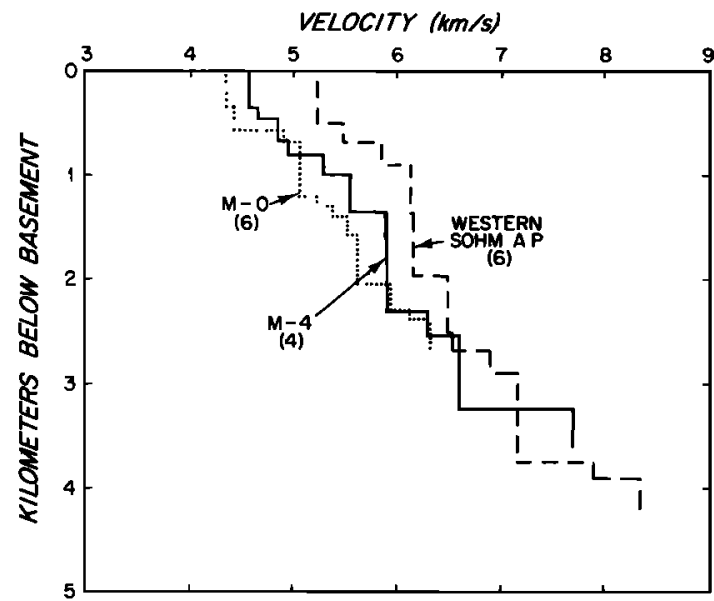

Fig. 11. Plot of velocity versus depth below basement averaged for each of three crustal age groups. Number of individual determinations used for each average is given in parentheses (see Table 1). The low average velocity for $0-0.5 \mathrm{~km}$ subbasement at $\mathrm{M-0}$ is due largely to inclusion of an anomalous $3.1 \mathrm{~km} / \mathrm{s}$ refractor observed in sonobuoy 221 . The same relative pattern of velocity distribution versus age group is observed if the total velocity range of each age group is plotted.

in younger strata; thus these faults appear to be comparable to the growth faults observed on the J Anomaly Ridge.

The smooth basement widely developed along the crest of the J Anomaly Ridge also suggests a subaerial origin, probably as a result of laterally extensive basalt flows coupled with subaerial erosion. In additon, subaerial erosion at sea level best explains the apparently truncated tops of tilted fault blocks near the ridge crest (see arrows, Figure 5).

The only direct sampling of the J Anomaly Ridge, accomplished on the shallower northern part of the ridge at DSDP site 384 (Figure 2), provides direct evidence of subaerial exposure. The crust there was formed at magnetic anomaly M-2 ( $\sim 113 \mathrm{Ma})$ and consists of normal tholeiitic basalts only slightly enriched in large ion lithophile (LIL) elements and of undistinguished magnetization [Tucholke et al., 1979]. Three lava flows were recovered, the lowest of which contains titanomagnetites altered by high-temperature deuteric oxidation that is typical of subaerial extrusion. The upper flows are altered by low-temperature, probably submarine, oxidation [Petersen et al., 1979]. Initial subaerial extrusion and/or later exposure also are indicated by high vesicularity of the basalts and by a basaltic 'soil' horizon presumably formed by intense subaerial weathering.

The basalt could have been above sea level for as much as several million years, after which upper Barremian or lower Aptian shallow-water carbonates accreted on the ridge. The carbonates were deposited until late Aptian or early Albian time ( 105-108 Ma). Petrographic and oxygen isotopic data indicate that the carbonates themselves were then subaerially exposed [Rothe, 1979; Rothe and Hoefs, 1979] before the ridge rapidly subsided to its present depth.

Given this geologic history, it is reasonable that the ridge crest farther south, in our survey area, also formed near sea level. Basement depth at site 384 , isostatically corrected for sediment loading, is $4100 \mathrm{~m}$. This is only $1400 \mathrm{~m}$ shallower than the comparably corrected basement depth of $5500 \mathrm{~m}$ over the southern part of the ridge. Thus while the $M-2$ age crust at site 384 was subsiding toward sea level, the $M-1$ to M-0 age crust farther south probably was accreting at sea level. Crustal accretion and erosion at zero depth seem to provide the best explanation of the available geological and geophysical observations.

The analogous development of the $J$ Anomaly Ridge and the 'Iceland phenomenon' extends beyond basement structure. The vertical and horizontal scales of the two systems are very much the same (Figure 8 ), and there is obvious similarity in the southward deepening axes of the $\mathrm{J}$ Anomaly and Reykjanes Ridge systems, with resultant southward pointing, V-shaped bathymetric patterns. These larger scale trends suggest that the J Anomaly Ridge system was formed by a mechanism like that responsible for the Iceland system.

Iceland is thought to result from effusion of excess magmas above a mantle plume or hot spot [e.g., Morgan, 1981]. In addition, increasing axial depths and systematic changes in chemistry of Reykjanes Ridge rift-axis basalts southwest from Iceland both have been attributed to the presence of the sub-Icelandic mantle plume [e.g., Schilling, 1973; Vogt, $1974,1976]$. These authors suggest that the ascending mantle-plume melts, which normally would migrate radially from the hot spot, are preferentially channeled into 'pipe flows' along and beneath the rift axis of the mid-ocean ridge. Head loss and progressive mixing of primary and mantle-plume melts away from the plume account for the observed topographic and geochemical effects. Vogt [1974] calculated that the migration rate of the plume melts is of the order of 50$200 \mathrm{~mm} / \mathrm{yr}$, very similar to the $50 \mathrm{~mm} / \mathrm{yr}$ southward migration of the topographic expression of the J Anomaly Ridge. All these considerations suggest that the $J$ Anomaly Ridge system originated by a hot spot mechanism or at least with the presence of a hot spot-like magma source. Discussion of this concept and evolution of the ridge system are outlined below.

\section{Evolution of J ANOMAly Ridge}

In Early Cretaceous time prior to formation of the $J$ Anomaly Ridge, the spreading axis of the Mid-Atlantic Ridge intersected the southwestern margin of the Grand Banks nearly at right angles. The spreading axis did not extend north into Laurasia but was offset along a major transform fault into the Tethys [e.g., Dewey et al., 1973]. The adjacent continental crust of Iberia (Iber) and the Grand Banks (GB) had experienced a probably Triassic-Liassic phase of rifting followed by relative inactivity during the Middle Jurassic [Sibuet and Ryan, 1979]. During the Late Jurassic and Early Cretaceous, GB-Iber rifting again commenced, and the first true drift and production of oceanic crust between these land masses are inferred to have occurred at the $J$ anomaly about the end of Aptian time ( $105 \mathrm{Ma}$; Sibuet and Ryan [1979] and Sullivan [1982]).

We propose that the J Anomaly Ridge and Madeira-Tore Rise originated in concert with, and possibly in response to, the late-stage rifting and initial drift between Iberia and the Grand Banks. Specifically, drawing on the Iceland analog, we suggest that partial melts from deep sources within the rift zone were funneled southward along subcrustal conduits and entered the spreading axis of the abutting Mid-Atlantic Ridge. Extrusion and intrusion of these melts at the spreading axis caused the Mid-Atlantic Ridge crest to accrete to elevations at and above sea level. Southward migration of this 'melt front' (and corresponding topographic anomaly) with time allowed the $\mathbf{J}$ Anomaly Ridge to be constructed across seafloor isochrons until about $108 \mathrm{Ma}$ (anomaly M-0, 


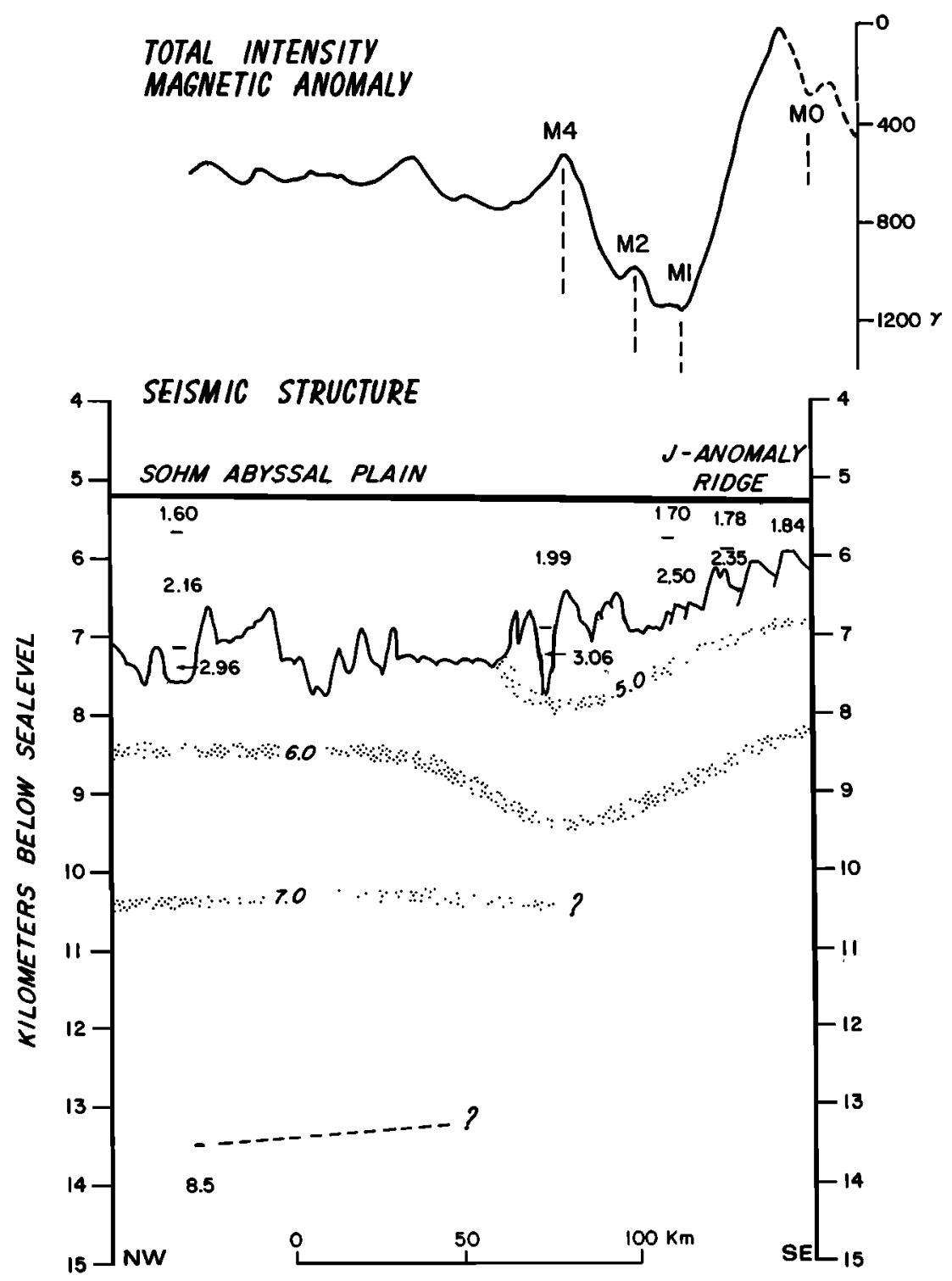

Fig. 12. Velocity-structure section and magnetic anomaly profile across the $\mathrm{J}$ Anomaly Ridge. The configuration of the basement layer is drawn from MCS line 152 (see Figure 5), and isovelocity contours are based on averages in Figure 11 ; mantle determination at left is from sonobuoy 235 .

Figure 8). If we extrapolate the rate of southward migration of the ridge $(50 \mathrm{~mm} / \mathrm{yr})$ back to the continental margin, the melt front probably was beneath the edge of the Grand Banks at about $120 \mathrm{Ma}$.

Two possible origins of the magma source seem attractive. One is the passage of the Grand Banks over a rising mantle plume or hot spot. Recent work by Morgan [1981, manuscript in preparation, 1982] suggests that the Labrador shelf passed over the Canaries hot spot and that the Grand Banks moved over the Madeira hot spot about 120-110 Ma. The Grand Banks and adjacent rift zone then remained over the Madeira hot spot continuously up to about $105 \mathrm{Ma}$. A problem with this model is that Morgan's relative position of the Madeira hot spot at $120 \mathrm{Ma}$ depends on inception of drift between the Grand Banks and Iberia about $80 \mathrm{Ma}$, whereas evidence presented below and by Sibuet and Ryan [1979] indicates that drift began at the end of the Aptian ( 105-108 Ma). Although this does not invalidate the possible role of a hot spot, we cannot clearly attribute the origin of the partial melt to a mantle plume until the hot spot trace is better constrained.

A second possible source for the magma is a large zone of partial melting beneath the GB-Iber rift system. The eastward relative movement of the Mid-Atlantic Ridge crest with respect to the GB-Iber rift zone may have brought the spreading axis to a location where it 'tapped' this melt zone. However, it is not clear that this kind of magma source would be volumetrically important in the absence of a mantle plume.

Presuming that the kinematic evolution, if not the dynamic mechanism of ridge formation proposed above, is valid, we can outline the following geologic history for the J Anomaly Ridge system as it related to the adjacent GB-Iber rift zone.

\section{Late-Rift Phase (120-113 Ma)}

The partial melt migrating southward from the GB-Iber rift zone (Figure 13) probably reached the Newfoundland Fracture Zone about $117 \mathrm{Ma}$ (anomaly M-4) and the latitude of 


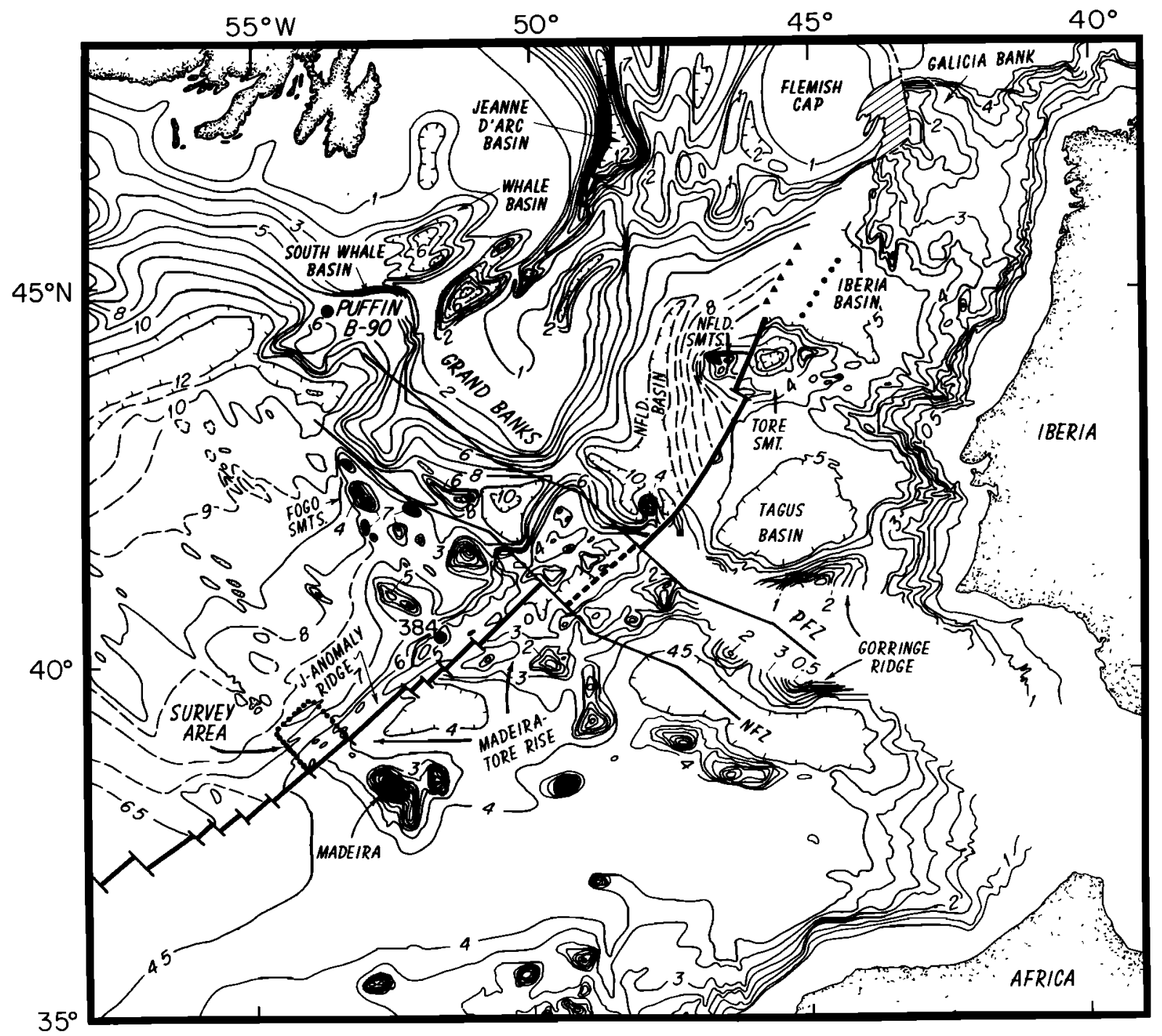

Fig. 13. Reconstruction of the North Atlantic to anomaly M-0 time (108 Ma), based on North America-AfricaIberia-Europe poles of rotation of K. Klitgord and H. Schouten (manuscript in preparation, 1982). Contours west of spreading-ridge axis (heavy line) are present depths to basement in kilometers below sea level [Tucholke et al., 1982; Jansa and Wade, 1975]; east of spreading center, regional depth-to-basement contours are not available, and bathymetric contours are used to illustrate the general shape of the Madeira-Tore Rise. The overlap (shaded) of Galicia Bank and Fiemish Cap is at the 5-km basement-depth cüintüur. The African and Iberian plates are arbitrarily separated along Gorringe Ridge. North of Tore Seamount the triangles locate the $\mathrm{J}$ anomaly on the Iberian plate [Groupe Galice, 1979], and the dots locate a possible J anomaly over Flemish Cap Ridge on the North American plate [Sullivan, 1982]; to the south, the rotated J anomalies are coincident. Pico Fracture Zone and Newfoundland Fracture Zone are symbolized by synthetic flow lines (K. Klitgord and H. Schouten, manuscript in preparation, 1982); these flow lines follow basement structural trends quite closely.

site 384 about $114 \mathrm{Ma}$ (anomaly M-3). This is presumed to be reflected in the southward extension of subaerially accreting crust along the Mid-Atlantic Ridge. We know that by $113 \mathrm{Ma}$ (anomaly M-2), basalts were being extruded subaerially at site 384 on the Mid-Atlantic Ridge crest. Farther south, the spreading axis probably was below sea level (Figures 3 and 5). No true oceanic crust had yet formed in the GB-Iber rift zone.

\section{Rift-Drift Transition (112-108 Ma)}

Between anomalies M-1 and M-0 (upper Barremian to middle Aptian), the melt front and topographic expression of the ridge migrated south to a (present) latitude of about $38^{\circ} \mathrm{N}$ (Figure 8). The ridge probably accreted to heights near or slightly above sea level along its entire length, and subaerial basalt flows locally formed the characteristic eastward dipping subbasement reflectors observed in our multichannel seismic lines (Figure 5). Subaerial erosion peneplaned this crust to form the unusually smooth basement surface. Slightly older crust had partially cooled and subsided; this crust was block-faulted along west dipping fault planes and some of the blocks were rotated (Figure 5). Erosion products from the adjacent subaerial crust probably helped smooth and mask the basement surface of this older crust. At site 384, the crust subsided below sea level, and reef carbonates accumulated.

\section{Drift Phase ( $108 \mathrm{Ma})$}

We suggest that the first emplacement of true oceanic crust between Iberia and the Grand Banks began at this time 
(about anomaly M-0). The thermal anomaly and minor regional uplift that are postulated to accompany this continental breakup [Falvey, 1974] seem to explain best two unusual facets of the J Anomaly Ridge: (1) the temporary, late Aptian or early Albian uplift and subaerial exposure of the reef carbonates at site 384 and (2) the apparent uplift and subaerial truncation of corners of tilted fault blocks near the ridge crest (arrows, Figure 5). These minor, although important, features would correlate with Falvey's 'breakup unconformity.' Furthermore, the entire ridge system apparently experienced unusually rapid subsidence shortly following anomaly M-0. We attribute this to rapid decay of the initial thermal regime that accompanied the breakup, and we suggest that the mid-oceanic ridge axis rapidly evolved to near-normal depths greater than $2000 \mathrm{~m}$.

\section{Discussion}

The suggested timing of the above events correlates closely both with Falvey's [1974] model of continental brtakup and with observations of regional geology. Falvey predicted two phases of uplift during the rifting history of a passive continental margin. The first could occur well before $(>50 \mathrm{Ma}$ ) the initiation of true drift and consists of regional uplift over the rift zone in response to a thermal anomaly impinging on the base of the lithosphere. The second is predicted to be a 'short, sharp' period of uplift associated with convective heat transport at the time of breakup. A period of relative subsidence is thought to occur between these phases, possibly as a result of thermal metamorphism [Falvey, 1974].

The early-rift uplift correlates with widespread development of an erosional unconformity over the Grand Banks, Orphan Knoll, Galicia Bank, and in the Lusitanian and Aquitanian basins of Europe [Amoco and Imperial, 1974; Gradstein et al., 1975; Jansa and Wade, 1975; Ruffman and van Hinte, 1973; Laughton et al., 1972; Sibuet and Ryan, 1979; Dardel and Rosset, 1971; Winnock, 1971]. The unconformity is typified in Grand Banks wells, where the hiatal gap usually spans the Late Jurassic through middle Cretaceous (Aptian). Thus, following initial uplift, subsidence over most of the Grand Banks apparently was so slight that no Lower Cretaceous marine sequences accumulated. We have suggested that the adjacent oceanic crust of the J Anomaly Ridge system also was subaerially exposed; hence the Lower Cretaceous unconformity may be continuous across both continental crust and the oceanic crust of the ridge.

There are two kinds of locations where this widespread hiatal development may have been restricted to a shorter time interval. One is in basins which initially were less elevated or which subsided so rapidly that Lower Cretaceous marine sedimentary sequences could accumulate. Examples occur along the southwest margin of the Grand Banks in the South Whale Basin (Puffin B-90 well, Gradstein et al. [1975]; Amoco and Imperial [1974]) and over Galicia Bank [Sibuet and Ryan, 1979]. The Newfoundland, Iberia, and Tagus basins probably also accumulated Lower Cretaceous marine sequences, and they may have been so deep that no hiatus developed (Figure 13). A second, very localized, restriction of unconformity development probably occurred at loci of subaerial volcanism. Volcaniclastics and lavas of mixed Late Jurassic-Aptian ages can be expected to interrupt and overlie the synrift unconformity throughout the region.
We correlate the 'short, sharp breakup unconformity' with subaerial exposure of the reef at site 384 and with truncation of the corners of tilted fault blocks on the J Anomaly Ridge, and we place the time of initial drift between Iberia and the Grand Banks at anomaly M-0 ( $108 \mathrm{Ma}$, late Aptian). Similar manifestations of brief subaerial exposure probably occur on other basement ridges and seamounts in this region. In deeper basins the breakup unconformity probably is not developed, but some shallower basinal sediments may have been briefly exposed. A possible example of the latter occurs in the South Whale Basin (Amoco and Imperial [1974], their Figure 9) where the Puffin B-90 well encountered nonmarine facies and an overlying unconformity in the Aptian-Turonian section. In most other areas the uplift either caused reexcavation of the earlier synrift unconformity or maintained the subaerial exposure and excavation inherited from the previous uplift. Regional subsidence shortly following the breakup event allowed Upper Cretaceous marine facies to become widely distributed across the Grand Banks [Gradstein et al., 1975].

Our placement of the ocean-continent boundary between Iberia and the Grand Banks at anomaly M-0 ( $\mathrm{J}$ anomaly) has several interesting consequences. First is the implication that there is deeply subsided continental crust $(8+\mathbf{k m})$ beneath the Newfoundland, Tagus, and Iberia basins (Figure 13). The depth of these basins perhaps is not too surprising because the Jeanne D'Arc Basin beneath the Grand Banks has more than $12 \mathrm{~km}$ of Mesozoic/Cenozoic fill (Figure 13), but the size of the basins is significantly larger and their sedimentary fill is much smaller $(\sim 5 \mathrm{~km})$. These basins may contain continental crust that was extensively thinned (and intruded) during the rifting phase. Margin basins of similar size and depth occur farther north in the Flemish Pass and the Orphan Basin. Refraction work there by Keen and Barrett [1981] suggests that extensively thinned ( 50\%) continental crust underlies the basins and that total crustal thickness is $15-17 \mathrm{~km}$, including up to $\sim 5 \mathrm{~km}$ of Cretaceous/ Tertiary sediment.

A second consequence of postulating that breakup did not precede anomaly M-0 is that Flemish Cap and Galicia Bank exhibit minimal overlap (Figure 13). The $70-\mathrm{km}$ overlap north of Tore Seamount in the $\mathrm{M-0}$ reconstruction might be explained by subsequent extension (spreading?) east of Galicia Bank (extensional basins of Réhault and Mauffret [1979]) and/or possibly in the deep graben west of Flemish Cap [Haworth and Keen, 1979].

Finally, the westernmost Newfoundland Seamounts and Tore Seamount are formed very near the ocean/continent boundary but on presumed continental crust. This raises the interesting possibility that the unusual ring structure of Tore Seamount actually is a collapsed caldera formed under subaerial conditions. Laughton et al. [1975] considered this possibility but dismissed it because of the unusually large magma chamber that would be necessary. However, if the seamount formed near a newly developed spreading center subject to mantle-plume influence, the explanation may not be so unrealistic as was once thought.

The position of the ocean/continent boundary south of the Grand Banks is equally interesting. The data and model that we have presented for the J Anomaly Ridge system indicate that only oceanic crust occurs south of the Newfoundland Fracture Zone (Figure 13). We also suggest that oceanic crust extends northward to the Pico Fracture Zone near the edge of the Grand Banks. Seismic refraction profiles just south- 
west of the Grand Banks appear to confirm the occurrence of oceanic crust seaward of the Pico Fracture Zone [Jackson et al., 1974]. In contrast, Grant [1977, 1979] inferred from the observed distribution of the Lower Cretaceous unconformity in seismic reflection records that continental crust was present in this region beneath the Southeast Newfoundland Ridge. However, as noted earlier, the unconformity could be continuous over both continental and oceanic crust. Furthermore, if continental crust were present between these fracture zones off the Grand Banks, we would also expect continental crust to occur in conjugate areas of the eastern Atlantic, for example within the strongly deformed Gorringe Ridge. Neither geophysical or dredge results indicate the presence of continental crust there [e.g., Purdy, 1975]. If oceanic crust in fact is present immediately southwest of the Grand Banks, the two southwest trending basement highs there require explanation (Figure 13). It is possible that they are earlier formed versions of the J Anomaly Ridge, emplaced at the crest of the Mid-Atlantic Ridge as it migrated eastward along the Grand Banks transform margin.

While the structural origin of the $J$ Anomaly Ridge/ Madeira-Tore Rise system can be correlated rather well with the history of rifting between Iberia and the Grand Banks, the origin of the $\mathrm{J}$ magnetic anomaly itself remains uncertain. The restriction of anomalous magnetization to the zone between anomalies M-1 and M-0 [Rabinowitz et al., 1979] suggests a direct relation to the final rifting and initial drift between Iberia and the Grand Banks. Any satisfactory model, however, must also explain the apparently decaying amplitude of the $\mathrm{J}$ anomaly both northward and southward from the Southeast Newfoundland Ridge [Keen et al., 1977; Groupe Galice, 1979; Rabinowitz et al., 1979].

Before considering the mechanism by which the anomalous magnetization was produced, we should discuss its source. The absence of any significant gravity anomaly over the J Anomaly Ridge and the normal velocity structure (excepting the thickened layer 2B) eliminate the possibility that the anomaly is produced by intrusions of dense materials such as intensely magnetized gabbros or chromiumspinel-bearing ultrabasic rocks [Tucholke and Vogt, 1979]. However, induced magnetization caused by the presence of a large body of serpentinized peridotite cannot be discounted. Similarly, emplacement of unusually magnetized rocks because of late-stage magma differentiation, thermal boundary effects, or passage over a mantle plume are viable alternatives. Finally, an unusually thick magnetic layer may be present. This possibility may be supported by the presence of a layer 2B that is up to $2 \mathrm{~km}$ thick beneath the $J$ Anomaly Ridge, compared with about $1-\mathrm{km}$ thicknesses in both younger crust [Houtz and Ewing, 1976] and older crust (pre-M-4, Figure 12). The magnitude of the velocities almost certainly has changed with time (i.e., the layer 2A-2B conversion of Houtz and Ewing [1976]), but the relative lateral differences in velocity probably reflect initial differences in crustal structure. Thus the original layer $2 \mathrm{~A}$ (and the magnetic layer) at the ridge crest may have been twice as thick as normal.

The mechanism by which the anomalous magnetic body was emplaced perhaps is easier to explain. Although there are uncertainties about the past location of hot spots in this region, the presence of a mantle plume beneath the adjacent Southeast Newfoundland Ridge at anomaly M-1 to M-0 most conveniently explains the north-south distribution of anomaly amplitudes. Again referring to the Iceland analog [Schil- ling, 1973], radial flow from the plume probably would be concentrated along rift-axis conduits toward the south (and toward the north unless attenuated in the continental rift zone). Progressive mixing of anomalous mantle-plume melts with primary rift-axis magmas along the conduits could produce a trend of decreasingly magnetized crustal rocks with distance from the plume. Or emplacement of excess magma nearer the plume may simply have produced a thicker magnetic layer. The presence of a mantle plume also could explain several other observations:

1. The steplike decay in anomaly amplitude north of the Newfoundland Seamounts, south of $38^{\circ} \mathrm{N}$, and again at the New England Seamounts: these locations appear to be significant structural boundaries (fracture zones?) in the crust, where 'pipe flow' from a mantle plume would be attenuated or blocked [e.g., Vogt, 1974].

2. The timing of actual occurrence of breakup at anomaly M-0: arrival of an especially weakened zone of rifted continental crust over a mantle plume could explain the initiation of true drift.

3. The anomalously rapid subsidence of the J Anomaly Ridge, Southeast Newfoundland Ridge, and probably parts of the adjacent continental crust following anomaly $\mathrm{M}-0$ : subsidence at rates significantly faster than predicted by the conventional $t^{1 / 2}$ relation might be explained by a loss of dynamic uplift if a mantle plume either became inactive or migrated away from the region following GB-Iber breakup.

\section{Conclusions}

The J Anomaly Ridge and Madeira-Tore Rise are paired aseismic rises formed by excess volcanism at the crest of the Mid-Atlantic Ridge between about anomaly M-4 and M-0. The edifice-building volcanism that formed these ridges migrated southward at about $50 \mathrm{~mm} / \mathrm{yr}$, constructing much of the ridge system to and above sea level. This construction and migration appear to have been triggered when the eastward moving Mid-Atlantic Ridge axis arrived at and 'tapped' a large magma source (possibly a mantle plume) beneath the GB-Iber rift zone. The mantle plume concept most readily explains both the large magma source necessary to form the ridge system and the eventual formation of the J magnetic anomaly.

The evolution of the J Anomaly Ridge/Madeira-Tore Rise system is intimately related to the GB-Iber rift-drift sequence. The widespread 'synrift' unconformity over the adjacent continental margins appears to be laterally continuous with a subaerially eroded unconformity developed on oceanic crust of the $J$ Anomaly Ridge and probably the Southeast Newfoundland Ridge. The short, sharp 'breakup unconformity' [Falvey, 1974] at or shortly following M-0 is manifested on the J Anomaly Ridge by brief subaerial exposure of Aptian reefal carbonates and by truncation of the corners of tilted fault blocks. On the adjacent continental margins the breakup unconformity mostly is superimposed on the 'synrift' unconformity, but in deeper basins it may not be present, depending upon local uplift/subsidence histories.

Following the initiation of true drift between Iberia and the Grand Banks, the J Anomaly Ridge, the Madeira-Tore Rise, and probably other adjacent oceanic and continental crustal segments subsided at rates significantly greater than those expressed by the normal $t^{1 / 2}$ relation. The northern part of the oceanic J Anomaly Ridge and the continental crust beneath the adjacent Grand Banks subsided at very similar rates [Gradstein et al., 1977]. However, other crustal seg- 
ments appear to have had significantly different subsidence rates (even within the $\mathrm{J}$ Anomaly Ridge), and a single regional subsidence curve may not be applicable.

The model developed here agrees with available geological and geophysical data but needs further testing. Probably the best tests will be found in carefully planned seismic refraction and multichannel seismic reflection surveys across the proposed ocean-continent boundaries around the Grand Banks. Although similar work in the eastern North Atlantic will be useful, it must contend with Late Cretaceous and Tertiary tectonic and volcanic modification of crust caused by relative plate motions within the 'Eurasian plate' and between Eurasia and Africa.

Acknowledgments. This research was supported by the Office of Naval Research, contracts N00014-75-C-0210 and N00014-80-C0098 to Lamont-Doherty Geological Observatory and contract N00014-79-C-0071 to Woods Hole Oceanographic Institution. C. C. Windisch served as Chief Scientist on R/V Conrad cruise 21, leg 11. We thank the officers and crew of R/V Conrad for their assistance. The OBH measurements were made under the direction of $J$. Diebold. We also thank H. Schouten and K. Klitgord for providing unpublished poles of rotation for the reconstruction in Figure 13, W. J. Morgan for providing a preprint of his paper on North Atlantic hot spot traces, and C. E. Keen for making us aware of K. D. Sullivan's work in the Newfoundland Basin. M. Sundvik and S. Rappelyea provided technical assistance. The manuscript was reviewed by J. I. Ewing, G. M. Purdy, and E. Uchupi, who made many helpful comments. Contribution 5117 of Woods Hole Oceanographic Institution and contribution 3382 of Lamont-Doherty Geological Observatory.

\section{REFERENCES}

Amoco Canada Petroleum Co. Ltd. and Imperial Oil Limited, Offshore Exploration Staffs, Regional geology of Grand Banks, Am. Assoc. Pet. Geol. Bull., 58, 1109-1123, 1974.

Bodvarsson, G., and G. P. L. Walker, Crustal drift in Iceland, Geophys. J. R. Astron. Soc., 8, 285-300, 1964.

Carmichael, D., W. J. Ludwig, J. Ewing, G. Carpenter, and A. C. Hubbard, A pop-up ocean bottom hydrophone, Mar. Geophys. Res., 3, 225-228, 1977.

Chroston, P. N., C. J. Evans, and C. Lee, Laboratory measurements of compressional wave velocities and electrical resistivity of basalts from D.S.D.P. leg 49, Initial Rep. Deep Sea Drill. Proj., 49, 761-763, 1979.

Dardel, R.A., and R. Rosset, Histoire géologique et structurale du bassin de Parentis et de son prolongement en mer, in Histoire Structurale du Golfe de Gascogne, vol. 2, pp. 1-28, Technip, Paris, 1971.

Davis, E. E., C. R. B. Lister, and B. T. R. Lewis, Seismic structure of the Juan de Fuca Ridge: Ocean bottom seismometer results from the median valley, J. Geophys. Res., 81, 3541-3555, 1976.

Dewey, J. F., W. C. Pitman, III, W. B. F. Ryan, and J. Bonnin, Plate tectonics and the evolution of the Alpine System, Geol. Soc. Am. Bull., 84, 3137-3180, 1973.

Egloff, J., and G. L. Johnson, Erosional and depositional structures of the southwest Iceland insular margin: thirteen geophysical profiles, Geological and Geophysical Investigations of Continental Margins, edited by J. S. Watkins, L. Montadert, and P. W. Dickerson, Mem. Am. Assoc. Pet. Geol., 29, 43-63, 1979.

Ewing, J., and M. Ewing, A telemetering ocean bottom seismograph, J. Geophys. Res., 66, 3863-3878, 1961.

Falvey, D. A., The development of continental margins in plate tectonic theory, APEA J., 14, 95-106, 1974.

Francis, T. J. E., I. T. Porter, R. D. Lane, P. J. Osborne, J. E. Pooley, and P. K. Tomkins, Ocean bottom seismograph, Mar. Geophys. Res., 2, 195-213, 1975.

Gradstein, F. M., G. C. Williams, W. A. M. Jenkins, and P. Ascoli, Mesozoic and Cenozoic stratigraphy of the Atlantic continental margin, eastern Canada, Canada's Continental Margins and Offshore Petroleum Exploration, edited by C. S. Yorath, E. R. Parker, and D. J. Glass, Mem. Can. Soc. Pet. Geol., 4, 103-131, 1975.
Gradstein, F. M., A. C. Grant, and L. F. Jansa, Grand Banks and the J-Anomaly Ridge: A geologic comparison, Science, 197, 10741076, 1977.

Grant, A. C., Multichannel seismic reflection profiles of the continental crust beneath the Newfoundland Ridge, Nature, 270, 22$25,1977$.

Grant, A. C., Geophysical observations bearing upon the origin of the Newfoundland Ridge, Tectonophysics, 59, 71-81, 1979.

Groupe Galice, The continental margin off Galicia and Portugal: Acoustical stratigraphy, dredge stratigraphy, and structural evolution, Initial Rep. Deep Sea Drill. Proj., 47(2), 633-662, 1979.

Haworth, R. T., and C. E. Keen, The Canadian Atlantic margin: A passive margin encompassing an active past, Tectonophysics, 59, 83-126, 1979.

Houtz, R. E., Crustal structure of the North Atlantic on the basis of large-airgun-sonobuoy data, Geol. Soc. Am. Bull., 91, 406-413, 1980.

Houtz, R. E., and J. I. Ewing, Upper crustal structure as a function of plate age, J. Geophys. Res., 81, 2490-2498, 1976.

Houtz, R., J. Ewing, and X. Le Pichon, Velocity of deep-sea sediments from sonobuoy data, J. Geophys. Res., 73, 2615-2641, 1968.

Jackson, R., C. E. Keen, and M. J. Keen, Seismic structure of the continental margins and ocean basins of southeastern Canada, Geol. Surv. Pap. Geol. Surv. Can., 74-51, 1-13, 1974.

Jansa, L. F., and J. A. Wade, Geology of the continental margin off Nova Scotia and Newfoundland, Offshore Geology of Eastern Canada, edited by W. J. M. Van der Linden and J. A. Wade, Geol. Surv. Pap. Geol. Surv. Can. 74-30, 51-106, 1975.

Keen, C. E., and D. L. Barrett, Thinned and subsided continental crust on the rifted margin of eastern Canada: Crustal structure, thermal evolution and subsidence history, Geophys. J. R. Astron. Soc., 65, 443-465, 1981.

Keen, C. E., B. R. Hall, and K. D. Sullivan, Mesozoic evolution of the Newfoundland Basin, Earth Planet. Sci. Lett., 37, 307-320, 1977.

Larson, R. L., and T. W. C. Hilde, A revised time scale of magnetic reversals for the Early Cretaceous and Late Jurassic, J. Geophys. Res., 80, 2586-2594, 1975.

Laughton, A. S., and R. B. Whitmarsh, The Azores-Gibraltar plate boundary, in Geodynamics of Iceland and the North Atlantic Area, edited by L. Kristjansson, pp. 63-81, D. Reidel, Hingham, Mass., 1974.

Laughton, A. S., et al., Site 111, Initial Rep. Deep Sea Drill. Proj., 12, 33-159, 1972.

Laughton, A. S., D. G. Roberts, and R. Graves, Bathymetry of the northeast Atlantic: Mid-Atlantic Ridge to southwest Europe, Deep Sea Res., 22, 791-810, 1975.

LePichon, X., J. Ewing, and R. Houtz, Deep-sea sediment velocity determination made while reflection profiling, J. Geophys. Res., $73,2597-2614,1968$.

LePichon, X., J.-C. Sibuet, and J. Francheteau, The fit of the continents around the North Atlantic Ocean, Tectonophysics, 28 , 169-209, 1977.

Ludwig, W. J., J. I. Ewing, and M. Ewing, Structure of Argentine continental margin, Am. Assoc. Pet. Geol. Bull., 52, 2337-2368, 1968.

Luyendyk, B. P., and E. T. Bunce, Geophysical study of the northwest African margin off Morocco, Deep Sea Res., 20, 537$549,1973$.

Morgan, W. J., Hotspot tracks and the opening of the Atlantic and Indian Oceans, in The Sea, vol. 7, edited by C. Emiliani, pp. 443487, John Wiley, New York, 1981.

Mutter, J. C., M. Talwani, and P. L. Stoffa, Origin of seawarddipping reflectors in oceanic crust off the Norwegian margin by "sub-aerial seafloor spreading," Geology, 10, 353-357, 1982.

Pálmason, G., Kinematics and heat flow in a volcanic rift zone, with application to Iceland, Geophys. J. R. Astron. Soc., 33, 451-481, 1973.

Pálmason, G., A continuum model of crustal generation in Iceland; kinematic aspects, J. Geophys., 47, 7-18, 1980.

Peterson, N., V. Bleil, and P. Eisenack, Rock- and paleomagnetism of leg 43 basalts, Initial Rep. Deep Sea Drill Proj., 43, 773-780, 1979.

Pitman, W. C., III, and M. Talwani, Sea-floor spreading in the North Atlantic, Geol. Soc. Am. Bull., 83, 619-646, 1972. 
Purdy, G. M., The eastern end of the Azores-Gibraltar plate boundary, Tectonophysics, 43, 973-1000, 1975.

Purdy, G. M., and R. S. Detrick, A seismic refraction experiment in the central Banda Sea, J. Geophys. Res., 83, 2247-2257, 1978.

Rabinowitz, P. D., S. Cande, and D. E. Hayes, Grand Banks and JAnomaly Ridge, Science, 202, 71-73, 1978.

Rabinowitz, P. D., S. Cande, and D. E. Hayes, The J Anomaly in the central North Atlantic Ocean, Initial Rep. Deep Sea Drill. Proj., 43, 879-885, 1979.

Réhault, J.-P., and A. Mauffret, Relationships between tectonics and sedimentation around the northwestern Iberian margin, Initial Rep. Deep Sea Drill. Proj., 47(2), 663-681, 1979.

Rothe, P., Shallow-water carbonates from site 384, Initial Rep. Deep Sea Drill. Proj., 43, 421-435, 1979.

Rothe, P., and J. Hoefs, Isotopic composition of Cretaceous shallow-water carbonates from site 384, Initial Rep. Deep Sea Drill. Proj., 43, 719-720, 1979.

Ruffman, A., and J. E. Van Hinte, Orphan Knoll-A "chip" off the North American "Plate," Earth Science Symposium on Offshore Eastern Canada, edited by P. J. Hood, Geol. Surv. Can. Geol. Surv. Pap., 71-23, 407-449, 1973.

Saemundsson, K., Vulkanismus und Tecktonik des Hengill-Gebietes in Sudwest Island, Acta Nat. Isl., 2(7), 195 pp., 1967.

Schilling, J. G., Iceland mantle plume: Geochemical study of Reykjanes Ridge, Nature, 242, 565-571, 1973.

Sibuet, J.-C., and W. B. F. Ryan, Site 398: Evolution of the west Iberian passive continental margin in the framework of the early evolution of the North Atlantic Ocean, Initial Rep. Deep Sea Drill. Proj., 47(2), 761-775, 1979.

Sullivan, K. D., The Newfoundland Basin: Ocean-continent boundary and Mesozoic seafloor spreading history, Earth Planet Sci. Lett., in press, 1982.

Sullivan, K. D., and C. E. Keen, On the nature of the crust in the vicinity of the Southeast Newfoundland Ridge, Can. J. Earth Sci., 15, 1462-1471, 1978.

Talwani, M., C. C. Windisch, P. L. Stoffa, P. Buhl, and R. E. Houtz, Multichannel seismic study in the Venezuela Basin and the Curacao Ridge, in Island Arcs, Deep Sea Trenches, and BackArc Basins, Maurice Ewing Ser., vol. 1, edited by M. Talwani and W. C. Pitman, III, pp. 83-98, AGU, Washington, D. C., 1977.
Tucholke, B. E., and P. R. Vogt, Western North Atlantic: Sedimentary history and aspects of tectonic evolution, Initial Rep. Deep Sea Drill. Proj., 43, 791-825, 1979.

Tucholke, B. E., et al., Site 384: The Cretaceous/Tertiary boundary, Aptian reefs, and the J-Anomaly Ridge, Initial Rep. Deep Sea Drill. Proj., 43, 107-165, 1979.

Tucholke, B. E., R. E. Houtz, and W. J. Ludwig, Sediment thickness and depth to basement in the western North Atlantic Ocean basin, Am. Assoc. Pet. Geol. Bull., 66, in press, 1982.

Uchupi, E., and J. A. Austin, Jr., The geologic history of the passive margin off New England and the Canadian Maritime Provinces, Tectonophysics, 59, 53-69, 1979.

Vogt, P. R., The Iceland phenomenon: Imprints of a hot spot on the ocean crust, and implications for flow below the plates, in Geodynamics of Iceland and the North Atlantic Area, edited by L. Kristjansson, pp. 105-125, D. Reidel, Hingham, Mass., 1974. Vogt, P. R., Plumes, subaxial pipe flow, and topography along the mid-oceanic ridge, Earth Planet. Sci. Lett., 29, 309-325, 1976.

Vogt, P. R., and A. M. Einwich, Magnetic anomalies and seafloorspreading in the western North Atlantic, and a revised calibration of the Keathley (M) geomagnetic reversal chronology, Initial Rep. Deep Sea Drill. Proj., 43, 857-876, 1979.

Watkins, N. D., Paleomagnetism of the Canary Islands and Madeira, Geophys. J. R. Astron. Soc., 32, 249-267, 1973.

Winnock, E., Geologie succinte du Bassin d'Aquitaine (contribution a l'histoire du Golfe de Gascogne), in Histoire Structurale du Golfe de Gascogne, vol. 1, pp. 1-30, Technip, Paris, 1971.

Zverev, S. M., I. V. Litvinenko, G. Palmason, G. A. Yaroshevskaya, N. N. Osokin, and M. A. Akhmetjev, A seismic study of the rift zone in northern Iceland, J. Geophys., 47, 191-201, 1980a.

Zverev, S. M., I. V. Litvinenko, G. Palmason, G. A. Yaroshevskaya, and N. N. Osokin, A seismic crustal study of the axial rift zone in southwest Iceland, J. Geophys., 47, 202-210, 1980b.

(Received March 31, 1982;

revised August 3, 1982;

accepted August 12, 1982.) 